OPEN ACCESS

Edited by:

Gitta Lasslop,

Senckenberg Biodiversity and Climate

Research Centre, Germany

Reviewed by:

Nicholas McCarthy,

Colorado State University,

United States

Owen Francis Price,

University of Wollongong, Australia

*Correspondence:

S. W. Taylor

steve.taylor@canada.ca

Specialty section:

This article was submitted to Interdisciplinary Climate Studies,

a section of the journal

Frontiers in Environmental Science

Received: 15 January 2020

Accepted: 28 August 2020

Published: 30 October 2020

Citation:

Taylor SW (2020) Atmospheric Cascades Shape Wildfire Activity

and Fire Management Decision

Spaces Across Scales -

A Conceptual Framework for Fire

Prediction

Front. Environ. Sci. 8:527278 doi: 10.3389/fenvs.2020.527278

\section{Atmospheric Cascades Shape Wildfire Activity and Fire Management Decision Spaces Across Scales - A Conceptual Framework for Fire Prediction}

\author{
S. W. Taylor* \\ Natural Resources Canada, Pacific Forestry Centre, Victoria, BC, Canada
}

This study uses an interdisciplinary approach to investigate variability in fire weather, fire activity and fire management decision spaces in western Canada from three separate perspectives. We used time series analysis to identify periodic and quasi-periodic components of fire weather measures at second, hourly, daily, yearly, and multi-decadal resolution in 3 ecozones. Examples of relationships between scales of fire weather and fire activity were taken from the literature. Through interviews with and observation of Canadian wildland fire management agencies we identified 20 typical decision problems which we mapped to 16 spatio-temporally cohesive decision spaces extending from incident to national levels and immediate to multi-decadal time spans. To connect these domains, we propose that space time cascades of atmospheric kinetic energy are reflected in an inverse cascade of wildfire activity, and shape the spatio-temporal dimensions of decision spaces and the pace of fire management decisions.

Keywords: fire weather, fire management, decision making, spectral analysis, scale

"Big whorls have little whorls, which feed on their velocity

And little whorls have lesser whorls, and so on to viscosity"

Lewis Fry Richardson, 1922

\section{INTRODUCTION}

Much early wildland fire research sought to relate changing daily weather to fire potential in fire danger rating systems to inform prevention and preparedness decisions (Taylor and Alexander, 2006; Hardy and Hardy, 2007). Growing recognition of the role of wildland fire in the Earth System and its ecosystems (Bowman et al., 2009), as well as the increasing socio-economic impacts of fire on many continents has stimulated a burst of new fire science in the past three decades in areas of climate change and Earth system processes, fire physics and behavior (Sullivan, 2017), fire management and analytics (Minas et al., 2012; Taylor et al., 2013; Martell, 2015; Jain et al., 2020), as well as in fire ecology (McLauchlan et al., 2020), and socio-economics. Abatzoglou and Kolden (2013) 
note that "the host of processes, timescales and sequences of atmospheric forcing that conspire in wildfire occurrence, behavior and growth, varies geographically and remains challenging to integrate in both research studies and operational fire management alongside the increasingly complex human environment."

Spatio-temporal variability in atmospheric quantities and processes important to fuel moisture, fire ignition and growth (e.g., lightning, solar radiation, temperature, relative humidity, potential evaporation, and wind speed) is a result of interactions between incoming solar radiation, land cover and oceanic and atmospheric circulation. While the mean atmospheric and surface temperature is primarily determined by the balance of incoming and outgoing radiation at the top of the atmosphere, incident solar radiation varies across the Earth's surface and over time due to daily and annual rotation of the Earth, axial tilt and orbital eccentricity. Spatio temporal differences in radiative heating are further modified by cloud cover and the albedo of the surface (e.g., water, vegetation, rock, snow, and ice). These gradients in surface heating set up horizontal and vertical pressure gradients, and atmospheric circulation. As was noted by Richardson (1922) atmospheric structures occur over a huge range of scales. Atmospheric eddies can have dimensions from a millimeter to thousands of miles and have lifespans seconds to months; climate variability extends further over millions of years (Lovejoy and Schertzer, 2010).

An international conference "Fire Prediction Across Scales" was held at Columbia University (Field et al., 2018) to synthesize research across the topics of fire prediction and fire management and impacts ${ }^{1}$. The objective of this interdisciplinary paper is to develop a conceptual framework linking fire weather, fire activity and management as a basis for integration, for framing predictive modeling, and to further understanding of whole system dynamics - it is a contribution to the special issue "Climate Land Use and Fire - Can Models Inform Management" arising from the conference.

Our proposition is that atmospheric energy cascades shape the pattern and tempo of fire weather, fire activity and fire management decisions across scales. Drawing on examples from western Canada, we examine fire weather, fire activity and fire management from three separate perspectives. The structure of the paper is as follows: In Section "Temporal Components of Fire Weather Index in Western Canada" we investigate periodic and quasi-periodic components in fire weather through analysis of the power spectra of the Fire Weather Index and the Monthly Drought Code of the Canadian Fire Weather Index System in western Canada. In Section "Fire Activity Across Scales" we review influences of fire weather on fire activity at different scales. We then map the temporal and spatial structure of fire management decision spaces in Canada in Section "Fire Management Decision Spaces." In Section "Synthesis" we bring these three threads together in new synthesis of atmospheric, fire activity, and fire management decision making scales.

\footnotetext{
${ }^{1}$ http://extremeweather.columbia.edu/events/past-events/2017-conference-onfire-prediction-across-scales/, accessed 01.06.20.
}

\section{TEMPORAL COMPONENTS OF FIRE WEATHER INDEX IN WESTERN CANADA}

Spectral, wavelet, and other time series analysis have been used to characterize periodicity in wind speed, temperature, and pressure. Van der Hoven (1957) identified spectral peaks in kinetic energy in a composite series of horizontal wind speed measurements at $100 \mathrm{~m}$ above surface at 4 days, $12 \mathrm{~h}$, and $1 \mathrm{~min}$ which he attributed to the passage of synoptic fronts, diurnal effects, and turbulence; this has classically been termed the Van der Hoven spectrum. Spectral analysis has also been used to identify ultra-long, long, and short waves with periods of $\sim 25$, 10 and 4-6 days, respectively, in $500 \mathrm{hPa}$ wind speeds in the northern Hemisphere (Fraedrich and Böttger, 1978)and in long and short waves in the southern Hemisphere (Fraedrich and Kietzig, 1983). Sources of intraseasonal and annual atmospheric variability include the Madden Julian Oscillation (MJO) and North Atlantic Oscillation (NAO) that primarily influence precipitation and the direction of storm tracks in the Pacific and Atlantic basins, respectively. Modes of low frequency variability associated with coupled atmospheric-oceanic (AO) circulation include the El Nino Southern Oscillation (ENSO), PDO (Pacific Decadal Oscillation), and Atlantic Multi-Decadal Oscillation (AMO) with quasi periods of approximately $2-3,20$, and 60 years, respectively. See Kaplan (2011) for a summary of these and other quasi periodic monthly, annular and multi-decadal anomalies. Very low frequency oscillations in temperature identified in Greenland and Antarctic ice cores extending to 110 kyr BP during the last ice age are attributed to orbital frequencies and ice sheet dynamics (Yiou et al., 1997). Spectral analysis naturally suggested classification of the spatial dimension and frequency of atmospheric features into a scale-based hierarchy (Orlanski, 1975; Fujita, 1981; Table 1); many authors have subsequently adapted or refined Orlanski's scheme. It is important to notes that atmospheric processes are continuous not discrete, and contemporary interpretations of atmospheric variability (e.g., Lovejoy and Schertzer, 2010) emphasize a continuous energy cascade over scale-bound phenomenological classifications. The atmospheric energy cascade is forward in some parts of the spectrum, and inverse in others and extends from seconds to millennia and centimeters to planetary dimensions. For a detailed survey and discussion of atmospheric space times cascades see Lovejoy and Schertzer (2012).

In this section we use spectral analysis to investigate whether these sources of atmospheric variability as well as daily and annual radiative forcing are apparent in the Fire Weather Index in western Canada. The FWI is an index of fire intensity where increasing values represent increasing intensity. Van Wagner (1987) scaled the standard FWI to fire intensity in red pine stands in ON, Canada:

$$
\text { FWI }=\mathrm{e}^{1.013 \times[\ln (0.289 \times 1)]^{0.647}}
$$

where I is frontal fire intensity $\left(\mathrm{kWm}^{-1}\right)$. Fire intensity has been correlated with FWI in other fire behavior field experiments in mature and immature jackpine stands, and jackpine slash in Ontario (Stocks and Walker, 1972; Stocks, 1987, 1989) and 
TABLE 1 | Some typical scales in meteorology and climatology (after Orlanski, 1975; Stull, 2017).

\begin{tabular}{llll}
\hline Scale & Wavelength & Period & Examples \\
\hline Microscale & $<2 \mathrm{~km}$ & $<1 \mathrm{~h}$ & Gusts \\
Mesoscale & $2-2000 \mathrm{~km}$ & $1 \mathrm{~h}-1$ month & $\begin{array}{l}\text { Slope winds, sea } \\
\text { breezes, } \\
\text { thunderstorms, fronts }\end{array}$ \\
Synoptic & $>500 \mathrm{~km}$ & $<1$ month & $\begin{array}{l}\text { Cyclones, anticyclones } \\
\text { Macroscale/ }\end{array}$ \\
intraseasonal & $>2000$ & 1 month & $\begin{array}{l}\text { Long waves, MJO, } \\
\text { monsoons }\end{array}$ \\
Global & planetary & $>1,>10$ years & ENSO, PDO
\end{tabular}

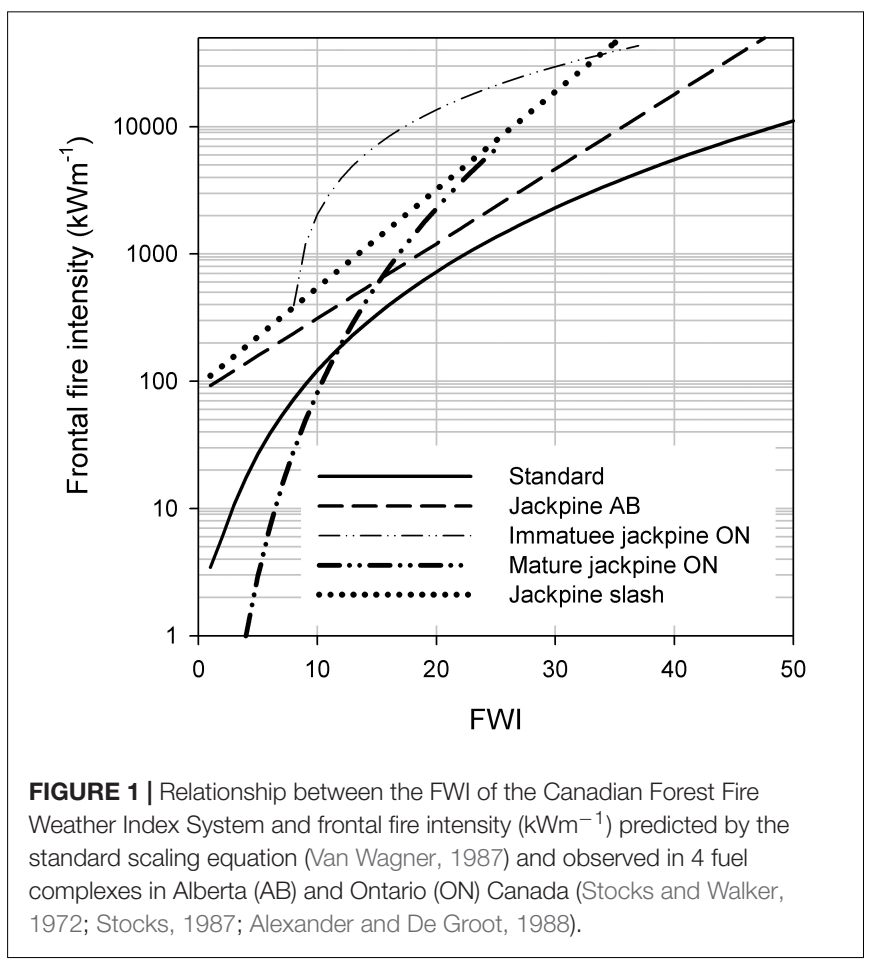

in jackpine stands in Alberta (Alexander and De Groot, 1988) shown in Figure 1. While the FWI-fire intensity correlation varies in different fuel complexes, fire intensity varies over 4 orders of magnitude from 10 to $>10,000 \mathrm{kWm}^{-1}$ in the range of FWI 1-50 in each case. Examples of potential fire behavior and fire suppression implications associated with FWI and corresponding fire intensity values for the standard condition are shown in Table 2. Fire intensity is correlated with biomass consumption in fires and is also a key factor in plant mortality due to lethal heating of cambium and roots or crown scorch (Ryan and Reinhardt, 1988; Alexander et al., 2019). While more complex and accurate models are used to predict fire spread and intensity in particular fuel complexes in operational practice (e.g., Forestry Canada Fire Danger Group, 1992; Andrews, 2014), the FWI is used in many fire climate research studies (e.g., Barbero et al., 2020 this issue) because it is a simple but robust indicator of fire activity. FWI is widely used as a danger index globally (Taylor and Alexander, 2006; Field, 2020) and is correlated with fire activity in many regions (Abatzoglou et al., 2018).

\section{Study Area and Data Compilation}

The study area encompasses the Pacific Maritime, Montane Cordillera, and Boreal Plain ecozones in western Canada (Wiken, 1986) which have a combined area of 1.38 million $\mathrm{km}^{2}$. These ecozones have distinct a spring and summer fire season (approximately May to October) which is separated by winter periods during or after which the moisture content of the surface organic layer is very high or fully saturated due to over winter precipitation as rain or snow, effectively limiting ignitions to near zero. Summer fire weather in western Canada is strongly affected by mid-tropospheric ridges and troughs, particularly the North Pacific High and Aleutian Low (Nadeem et al., 2019) which punctuate the predominant westerly zonal flow. Longer term weather, climate and fire activity in the region are influenced by ENSO and PDO (Meyn et al., 2010). We examined temporal periodicity in two fire weather quantities in the 3 ecozones from observations at $1 \mathrm{~Hz}$ to monthly resolution over observational periods from hours to a century.

We obtained fire weather and climate observations at four different sampling frequencies from stations at 3 sites in each of three ecozones that were co-located as closely as possible (Figure 2). The Pacific Maritime sites have $\mathrm{Cfb}$ and $\mathrm{Csb}$ Koppen-Geiger climates (temperate oceanic and warm summer mediterranean), the Montane Cordillera sites have Dfb and Dfc climates (warm summer humid continental and cool continental subarctic) and the Boreal Plain sites have a Dfb climate (Anonymous, 1958). Details on the location, weather observations and period of record for the 9 sites are in Table 3.

Weather observations were used to calculate the 6 interrelated codes and indexes of the Canadian Fire Weather Index System (Figure 3), namely the Fine Fuel Moisture Code, Duff Moisture Code, DC, Initial Spread Index, Buildup Index, and Fire Weather Index (Van Wagner, 1975) - the FFMC, DMC, DC, ISI, BUI, and FWI, respectively. The FFMC, DMC, and DC are indicators of the moisture content of 3 surface organic layers (needle litter and fine branch wood, $5-10 \mathrm{~cm}$ organic layers, and deep organic layers, respectively) with nominal time lags (time to lose $2 / 3$ moisture under standard drying conditions) of $18 \mathrm{~h}, 15$ and 53 days, respectively. With respect to the DC for example, gravimetric moisture contents sampled at 3 locations in western Canada were in the range $213-335 \%$ at DC 100 and $80-130 \%$ at DC 400 (Lawson and Dalrymple, 1996; Figure 4). The ISI combines fine fuel moisture and wind speed into an index of fire spread potential, the BUI represents organic layer fuel availability, and the FWI reflects potential fire intensity. For additional interpretive information on the FWI System the reader is referred to Wotton (2009).

\section{Monthly Climate}

Monthly observations of the average maximum daily temperature and total precipitation were obtained from Meteorological Service of Canada stations with an approximately 100 year record (Table 3). The Saanichton CDA station has a continuous 100 year record at the same location. However, we had to combine observations from 2 to 3 nearby stations to make up a 100 year record for the Prince George and Lost River/Nipawin sites, respectively. Combining observations from nearby stations in a 
TABLE 2 | Nominal frontal fire intensities, potential fire behavior and suppression implications (after Taylor and Alexander, 2017) for the Van Wagner (1987) FWI - Intensity scaling function.

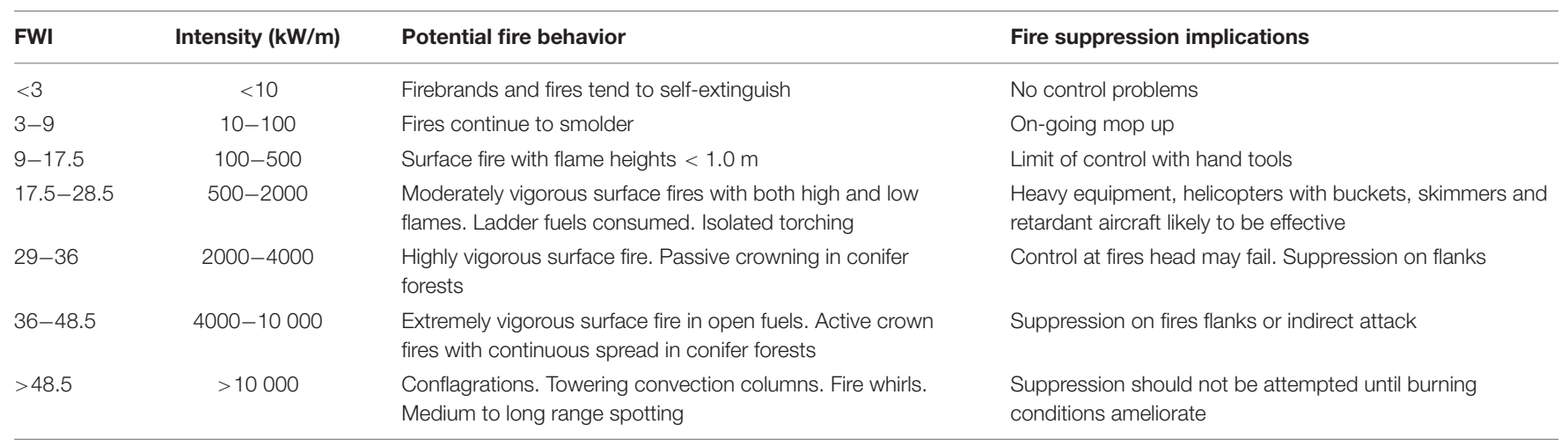

long term record many be more acceptable where the focus is on periodicity, rather long term trends (which are removed in the analysis). These data were used to calculate the Monthly Drought Code (MDC) for May-October. The MDC is an approximation of the average monthly Drought Code that can be estimated from monthly climate data (Girardin and Wotton, 2009). It was not possible to calculate the other daily FWI System values over a century because they require measures of daily noon or maximum/minimum relative humidity and wind speed that are rarely available for a continuous period at locations in Canada prior to the mid1900s.

\section{Daily and Hourly Weather}

Daily observations of temperature, relative humidity (RH), average wind speed over $10 \mathrm{~min}$, and total $24 \mathrm{~h}$ precipitation at 12:00 LST and hourly observations of the same quantities (excepting total precipitation at $1 \mathrm{~h}$ intervals) were obtained from remote automatic fire weather stations operated by the BC Wildfire Service and Saskatchewan Environment for the 2 locations in BC and 1 location in Saskatchewan, respectively. It should be noted that remote automatic fire weather stations are often not operated over the winter months because they are not equipped with instrumentation to measure precipitation as snow. The 12:00 daily observations were used to calculate the daily FFMC, DMC, DC, ISI, BUI, and FWI values. Days outside the fire season with no observations were filled with zeroes (for FWI). The hourly temperature, $\mathrm{RH}$, and wind speed observations were used to calculate $\mathrm{FFMC}_{h}$ (hourly FFMC; Van Wagner, 1977a) for the May-September fire season only. The moisture content of fine fuels represented by the FFMC is responsive to changes in temperature, $\mathrm{RH}$, and wind speed at this scale. Hourly wind speed was used with $\mathrm{FFMC}_{h}$ to calculate $\mathrm{ISI}_{h}$ and $\mathrm{FWI}_{h}$ (hourly ISI and FWI, respectively).

\section{High Frequency Wind Speed Observations}

One month samples of wind speed measured at $20 \mathrm{~Hz}$ using sonic anemometers and averaged to $1 \mathrm{~Hz}$ were obtained from two flux tower sites (DF-49 and OBS) that are part of the FluxNet Canada network and an associated site (MPB-03; Brown et al., 2012) in the 3 ecozones. Wind speed is only one of a number of meteorological quantities sampled at the flux towers in addition to $\mathrm{CO}_{2}$ flux; sampling methods are described in Fluxnet Canada Team (2016). The $1 \mathrm{~s}$ wind speed measures were combined with $\mathrm{FFMC}_{h}$ and daily BUI values from the hourly fire weather station at each location to estimate $\mathrm{FWI}_{s}(1 \mathrm{~s}$ FWI) using the following algorithm:

(1) FFMC $_{s}$ (1 s FFMC) was estimated using a linear interpolation to $1 \mathrm{~s}$ between successive $\mathrm{FFMC}_{h}$ values;

(2) FFMC $_{s}$ was used with the observed $1 \mathrm{~Hz}$ wind speed to calculate ISIs (1 s ISI) using the standard ISI equation (Van Wagner, 1987);

(3) $\mathrm{BUI}_{s}$ (1 s BUI) was estimated using a linear interpolation between the daily (12 pm) BUI values;

(4) $\mathrm{BUI}_{s}$ and $\mathrm{ISI}_{s}$ were then used to calculate $\mathrm{FWI}_{s}$ using the standard FWI equation (Van Wagner, 1987).

$\mathrm{FFMC}_{s}$ and $\mathrm{BUI}_{s}$ are likely not physically meaningful quantities because changes in surface fuel moisture are not measurable at a $1 \mathrm{~s}$ scale but were calculated so that ISI $_{s}$ and $\mathrm{FWI}_{s}$ would have a smoother response from hour to hour within and between successive days. However, we assume that fire spread and fire intensity potential, as represented by ISI and FWI, change with instantaneous changes in wind speed because in situ fire spread is observed to respond rapidly to changes in wind speed in field (Taylor et al., 2004) and laboratory fires (Albini, 1982).

\section{Spectral Analysis}

Because the focus of our paper was to develop illustrative examples rather than rigorous analysis of spectral properties we used relatively simple and well-known time series methods. Spectral analysis was used to test for the presence of signals of different frequency in the MDC and FWI time series data using the fast Fourier transformation incorporated in the SAS Spectra Procedure (Brocklebank et al., 2018). The data are centred around the mean (anomalies) before analysis. Fisher's Kappa statistic was used to test the hypothesis that variation in the time series is white noise. We used spectral analysis to test for energetic peaks in the MDC and FWI time series at 5 time scales and observational periods: 


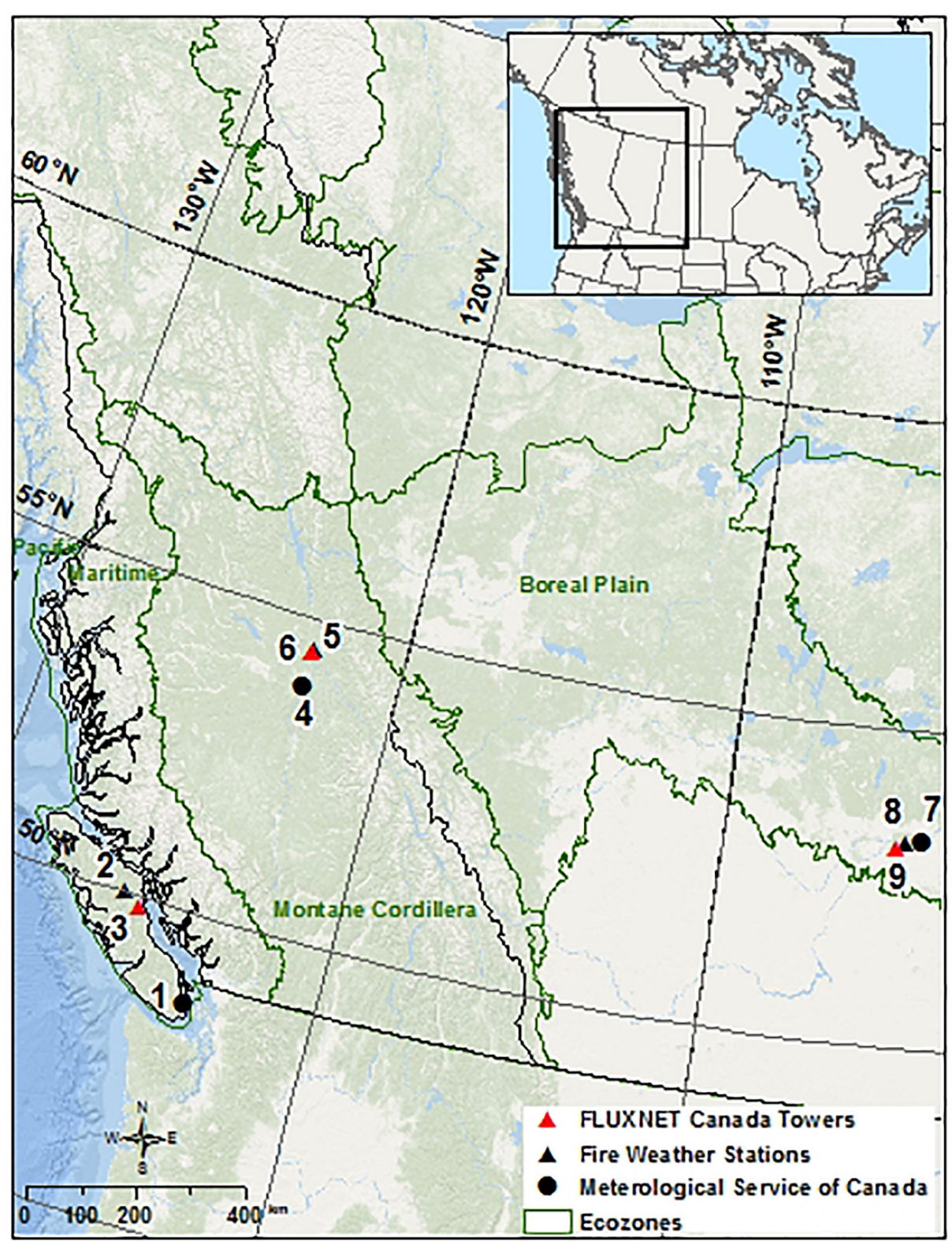

FIGURE 2 | Location of the 9 weather stations used in the spectral analysis of fire weather in the Pacific Maritime, Montane Cordillera, and Boreal Plain ecozones. Station names and details are in Table 2.

(T1) Annual values of the July MDC over approximately 100 years to test for ultra-low frequency peaks.

(T2) Daily FWI values for 25-40 year periods (including zeroes in the winter months) to test for low frequency, annual or seasonal peaks.

(T3) Daily FWI values for May-September in each of 10 years (2000-2009) to test for medium frequency peaks within the fire season.

(T4) Hourly FWI values (June-August) in each of 10 years (2000-2009) to test for daily and other cycles in the summer portion of the fire season.
(T5) Instantaneous (1 s) FWI for $1 \mathrm{~h}$ during the peak burning time (18:00) on 10 days to test for micro-scale energetic peaks.

Spectral peaks were identified visually in plots of the Power Spectral Density (PSD) against the period for tests where the hypothesis of white noise was rejected. The PSD is the Fourier transform of the autocorrelation function; PSD assigns units of spectral power per unit frequency, indicating how much of the signal is at a particular frequency $\omega$ (plotted as a period, the inverse of $\omega$ for convenience). 
TABLE 3 | Station locations and sample periods for monthly, daily, hourly, and $1 \mathrm{~s}$ weather/climate observations in three ecozones in western Canada.

\begin{tabular}{|c|c|c|c|}
\hline & \multicolumn{3}{|c|}{ Ecozone } \\
\hline & Pacific Maritime & Montane Cordillera & Boreal Plain \\
\hline \multicolumn{4}{|c|}{ Monthly maximum temperature and total precipitation } \\
\hline Station no./name & 1-Saanichton CDA & 4-Prince George / Prince George A & 7-Lost River/Nipawin A /Nipawin \\
\hline Climate & Csb & Dfb & Dfb \\
\hline Latitude ${ }^{\circ} \mathrm{N}$ & 48.6217 & $53.8333 / 53.8889$ & $53.2833 / 53.3333$ \\
\hline Longitude ${ }^{\circ} \mathrm{W}$ & -123.4189 & $-122.8000 /-122.6789$ & $-104.3333 /-104.0000$ \\
\hline Elevation (m) & 61 & $570 / 670$ & $375 / 372$ \\
\hline Sample period (by station) & $1914-2019$ & $1912-1945 / 1946-2019$ & $1918-1994 / 1995-2019$ \\
\hline \multicolumn{4}{|c|}{ Daily 12:00 temperature, relative humidity, 10 min average wind speed, 24 h precipitation - Hourly temperature, relative humidity, wind speed, precipitation } \\
\hline Station no./name & 2-Menzies Camp & 5-Bear Lake & 8-Fort La Corne \\
\hline Climate & Cfb & Dfc & Dfb \\
\hline Latitude ${ }^{\circ} \mathrm{N}$ & 50.04863 & 54.50922 & 53.2483 \\
\hline Longitude ${ }^{\circ} \mathrm{W}$ & -125.789 & -122.691 & -104.842 \\
\hline Elevation (m) & 438 & 739 & 474 \\
\hline Sample period (daily/hourly) & April-October 1970-2014/1992-2014 & April-October 1980-2014/1989-2014 & April-October 1989-2015/1989-2015 \\
\hline \multicolumn{4}{|c|}{ Horizontal wind speed at $20 \mathrm{~Hz}$ averaged to $1 \mathrm{~s}$} \\
\hline Station no./name & $3-D F-49$ & $6-\mathrm{MPB}-03$ & $9-\mathrm{OBS}$ \\
\hline Climate & $\mathrm{Cfb}$ & Dfc & Dfb \\
\hline Latitude ${ }^{\circ} \mathrm{N}$ & 49.8673 & 54.47333 & 53.9872 \\
\hline Longitude ${ }^{\circ} \mathrm{W}$ & -125.3336 & -122.7133 & -105.1178 \\
\hline Elevation (m) & 300 & 710 & 629 \\
\hline Sample period & July 15-Aug 15, 2009 & July 15-Aug 15, 2009 & May 1-30, 2011 \\
\hline
\end{tabular}

Stations numbers correspond to Figure 2.

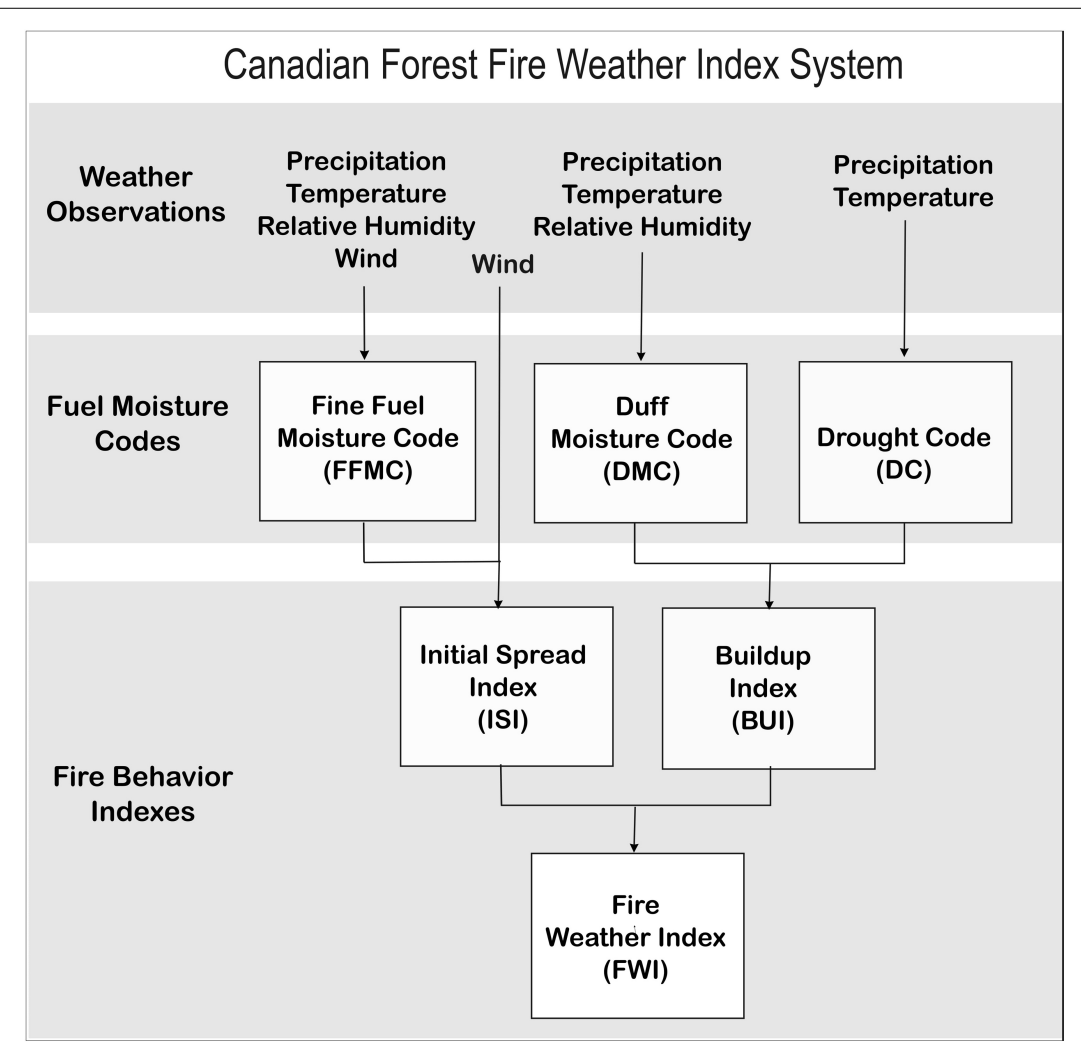

FIGURE 3 | Structure diagram of the Canadian Fire Weather Index (FWI) System. Reprinted from Taylor and Alexander (2006). 


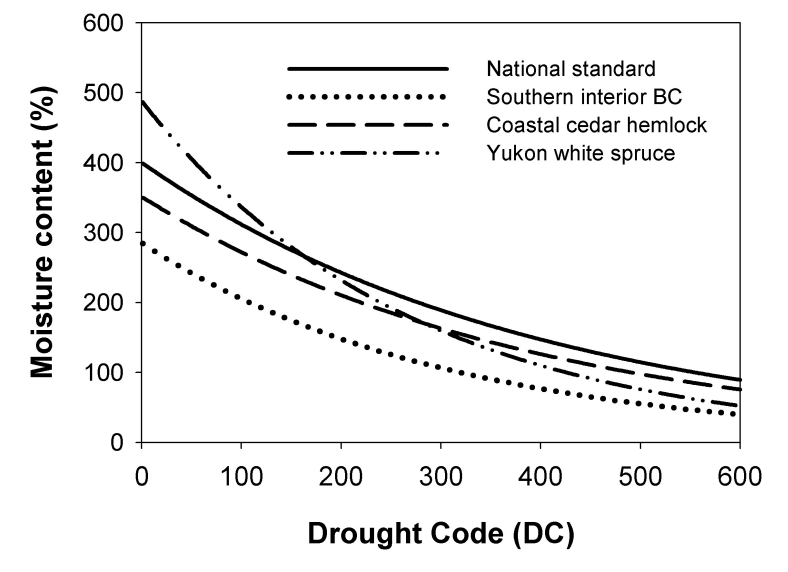

FIGURE 4 | Relationship between the Drought Code (DC) of the FWI System and the moisture content predicted in the standard function, and the moisture content of forest floor organic matter at $10 \mathrm{~cm}$ depth observed in 3 fuel complexes in western Canada (Lawson and Dalrymple, 1996).

In total we examined the spectral characteristics of approximately 100 fire weather time series from 5 periods at 4 temporal resolutions in 3 ecozones in western Canada (T1-T5 in Section "Temporal Components of Fire Weather Index in Western Canada"). Examples of the fire weather time series and corresponding spectral densities from the Montane Cordillera (Prince George, Bear Lake and MPB sites) are shown in Figure 5. The estimated spectral peaks are summarized Table 4, and are described briefly as follows:

(T1) In the analysis of 3 July MDC time series extending over approximately 100 years, the white noise hypothesis was rejected $(p>0.01)$ for the Saanichton and Prince George stations. Spectral peaks of 3.5 and 9 years were observed at both locations, as well as a 26 year peak at Prince George (Montane Cordillera ecozone). The white noise hypothesis was not rejected for the Lost River/Nipawin (Boreal Plains ecozone) dataset, which was a composite of 3 nearby stations.

(T2) The hypothesis of white noise in 3 multi-decadal series of daily FWI was rejected at all locations $(p>0.001)$. Not surprisingly, we observed very strong spectral peaks at 365 and 180 days corresponding to the annual cycle and the approximate fire season length in western Canada.

(T3) In our analysis of 30 series of daily FWI data for May September for 10 individual years, the white noise is rejected at all locations in all years $(p>0.001)$. Spectral peaks were observed in the order of 4 to 23 days, with the highest frequencies at 6 and 9, 12, and 12 days in the Pacific Maritime, Montane Cordillera, and Boreal Plains ecozones, respectively.

(T4) The hypothesis of white noise in the 39 time series of hourly FWI from June to August for 10 individual years was rejected at all locations in all years $(p>0.001)$. There were very strong $24 \mathrm{~h}$ (diurnal or daily) peaks in the FWI values. Peaks were also observed in the $48-390 \mathrm{~h}$ range
(2-16 days). Excluding the $24 \mathrm{~h}$ peaks, the median of the observed peaks was 140,130 , and $120 \mathrm{~h}$, in the Pacific Maritime, Montane Cordillera, and Boreal Plains ecozones, respectively $(5.8,5.4$, and 5 days).

(T5) Our analysis of $1 \mathrm{~s}$ FWI data was restricted to $1 \mathrm{~h}$ periods around the peak burning period (18:00-19:00) on each of 10 rain free days. The hypothesis of white noise is rejected in all of these time series at each location $(p>0.001)$. Spectral peaks were observed from 60 to $600 \mathrm{~s}$, with median values of 155,180 , and $160 \mathrm{~s}$ in the Pacific Maritime, Montane Cordillera, and Boreal Plains ecozones, respectively $(2.6,3$, and $2.7 \mathrm{~min})$.

\section{Summary}

The fire weather time series we examined exhibit, not surprisingly, very strong spectral peaks in Fire Weather Index values at annual and daily scales at all locations in the Pacific Maritime, Montane Cordillera, and Boreal Plains ecozones. We also observed quasi-periodic spectral peaks in fire weather measures at other scales, varying in strength and period length with location, time of year or time of day, and length of sampling period. The median spectral peaks in each ecozone were approximately $3 \mathrm{~min}$ consistent with turbulence in the late afternoon; spectral peaks were much stronger during the peak afternoon burning period that overnight. Spectral peaks in the order of 4-14 days were observed in June-August daily FWI values, consistent with the influence of blocking high pressure ridges and troughs that are characteristic of western Canadian fire seasons. The period lengths varied by year, possibly due to the frequency and persistence of blocking ridges, but this requires further investigation. Longer $>20$ day periods are in the same order as the MJO. There has been very little investigation of this mode of variability in the context of fire weather and so this connection is speculative, although Li et al. (2018) suggest that the MJO has a strong role in summer precipitation anomalies in western Canada. Spectral peaks were also observed in the Monthly Drought Code in the Montane Cordillera (Prince George) and Pacific Maritime (Saanichton) ecozones at 3.5 and 9-years, and at 26 years in the Montane Cordillera. From this limited information we do not speculate on casual connections with climate oscillations - analysis of other fire weather measures, stations and cross-spectral analysis with ENSO and PDO indices would be interesting. We did not observe mesoscale influences of slope winds or sea breezes for the study locations in this broad scale analysis; it is possible that sea breezes might be observed in the DF-49 data with more detailed analysis of wind direction.

The significance of the spectral peaks is that they are connected to the predictability of the fire weather measures at these scales (Palmer and Hagedorn, 2006; Krishnamurthy, 2019) and the utility of forecasts to fire management. For example, Corringham et al. (2008) examined opportunities to use monthly climate information in an annual fire management decision calendar.

It is clear that variation in annual, seasonal, and daily fire weather measures due to astronomical influences on radiation 

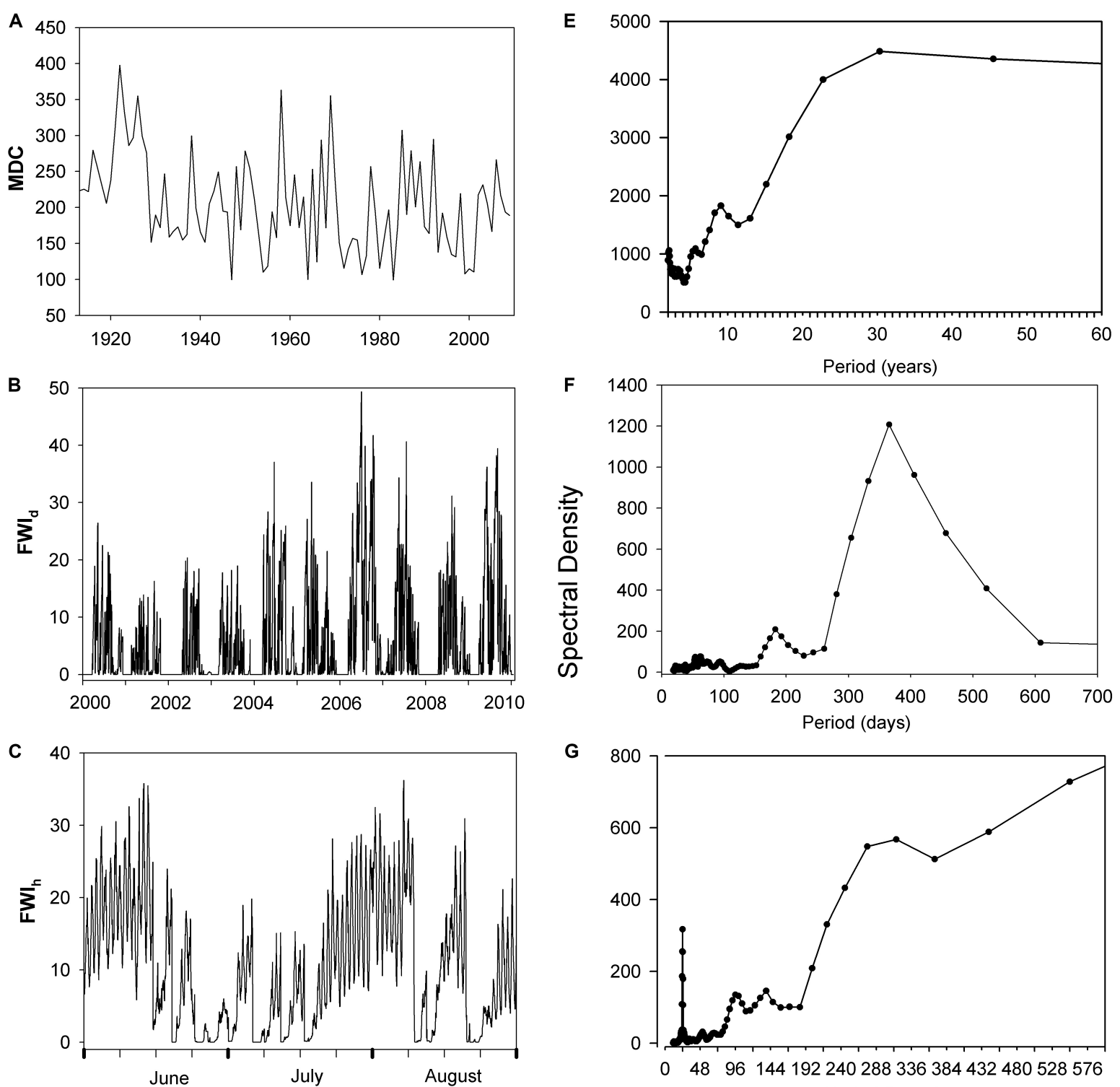

G
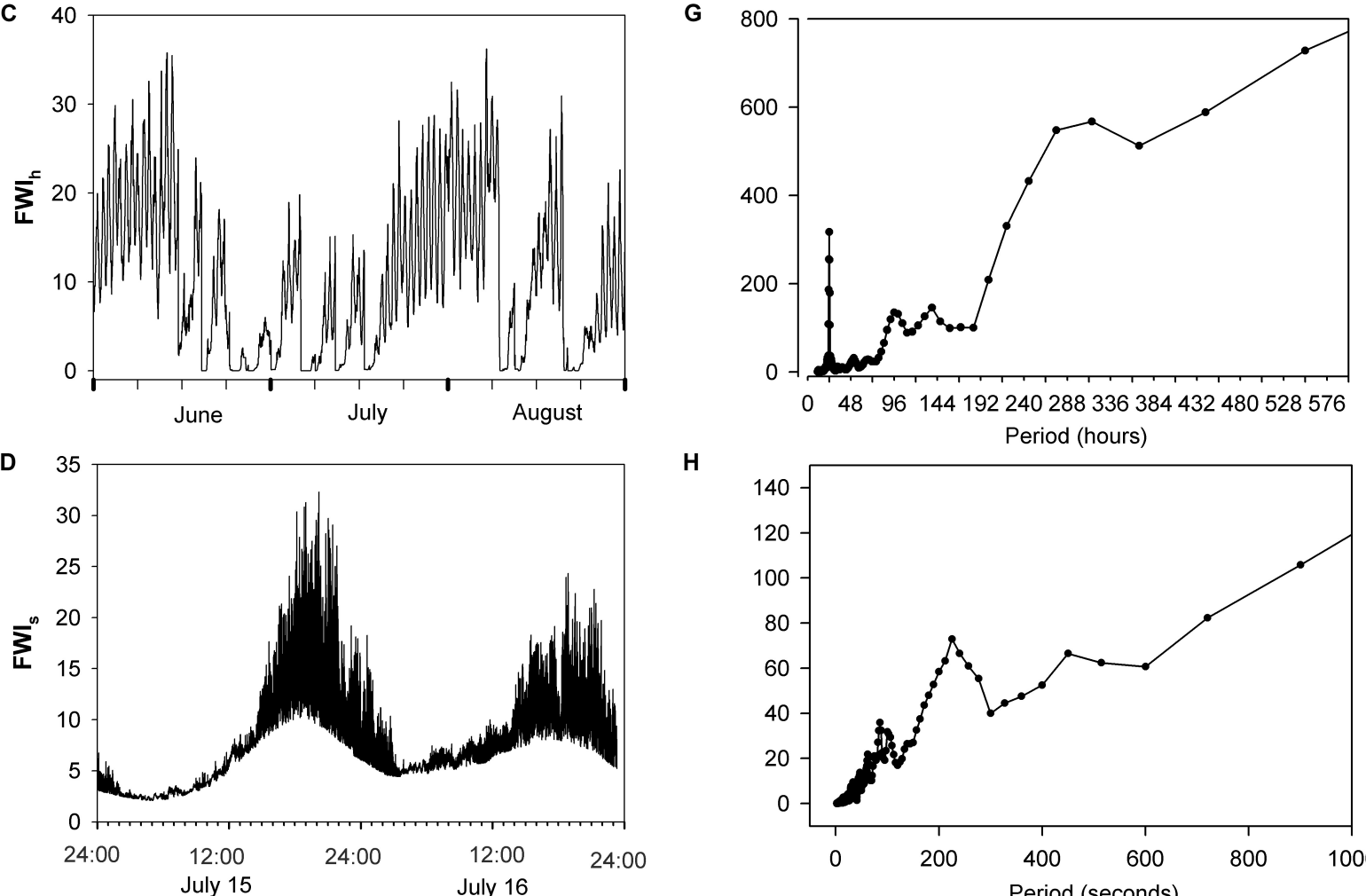

H Period (hours)

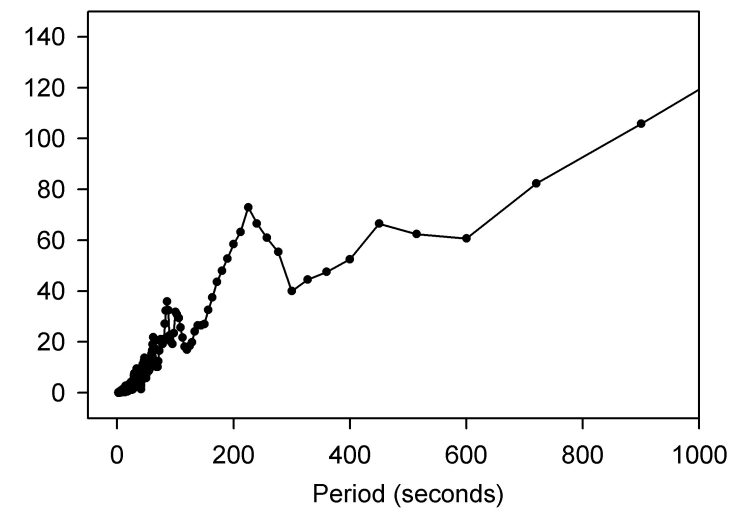

FIGURE 5 | Left panel: FWI System values (FWId, FWIh, FWls are the Fire Weather Index estimated at daily, hourly, and $1 \mathrm{~s}$ time scales, respectively.) observed at different time scales in the Montane Cordillera ecozone. (A) Monthly Drought Code during July, 1912-2018, Prince George, BC; (B) FWId during 2000-2010, Bear Lake, BC; (C) FWlh on June 1- August 31, 2009, Bear Lake, BC; (D) FWls for July 15-16, 2009, MPB-03 site (see Figure 1; Table 2). Right panel: (E-H) Power spectral density (PSD) corresponding to the time series in the right panel, excepting $\mathrm{H}$ is the power spectra for a $1 \mathrm{~h}$ sample 18:00-19:00 on July 15, 2009. 
TABLE 4 | Estimated spectral peaks (periods) in the Fire Weather Index (FWI) and the Monthly Drought Code (MDC) in 96 time series at annual, daily, and hourly resolution in 3 ecozones in western Canada.

\begin{tabular}{|c|c|c|c|c|c|}
\hline \multicolumn{2}{|c|}{ Pacific Maritime } & \multicolumn{2}{|c|}{ Montane Cordillera } & \multicolumn{2}{|c|}{ Boreal Plain } \\
\hline Sample Period yy:mm:dd (n) & Spectral Peaks & Sample Period yy:mm:dd (n) & Spectral Peaks & Sample Period yy:mm:dd (n) & Spectral Peaks \\
\hline \multicolumn{6}{|l|}{ T1 MDC (July by year) } \\
\hline $1918-2018(100)$ & $3.4,9$ & $1917-2019$ & $3.5,9,26$ & $1911-2019$ & NS \\
\hline \multicolumn{6}{|l|}{ T2 Daily FWI } \\
\hline $1980-2009(9000)$ & 365 & 1980-2009 (9000) & 180,360 & $1980-2009$ (9000) & 360 \\
\hline \multicolumn{6}{|c|}{ T3 Daily FWI (May-September, $n=160$ ) } \\
\hline 2000 & 10,23 & 2000 & 10,23 & 2000 & 6,15 \\
\hline 2001 & 5 & 2001 & 6,22 & 2001 & 6,12 \\
\hline 2002 & 10 & 2002 & 12 & 2002 & 5 \\
\hline 2003 & 9 & 2003 & 4,11 & 2003 & 12 \\
\hline 2004 & 9 & 2004 & 8,30 & 2004 & 9,14 \\
\hline 2005 & 9,17 & 2005 & 4,12 & 2005 & 7,12 \\
\hline 2006 & 11 & 2006 & 6 & 2006 & 7,23 \\
\hline 2007 & 8,23 & 2007 & 8,22 & 2007 & 5,10 \\
\hline 2008 & 13 & 2008 & 12 & 2008 & 13 \\
\hline 2009 & 13 & 2009 & 6,12 & 2009 & 11,18 \\
\hline \multicolumn{6}{|c|}{ T4 Hourly FWI (June-August, $n=2200$ ) } \\
\hline 2000 & $24,120,320$ & 2000 & $24,50,70,150,230$ & 1990 & $24,48,90,140$ \\
\hline 2001 & 24 & 2001 & $24,70,130$ & 1991 & $24,90,300$ \\
\hline 2002 & 24 & 2002 & $24,130,360$ & 1992 & $24,80,160$ \\
\hline 2003 & $24,90,140$ & 2003 & 24,100 & 1993 & $24,120,260$ \\
\hline 2004 & $24,120,220$ & 2004 & 24,90 & 1994 & $24,70,170,390$ \\
\hline 2005 & 24,240 & 2005 & $24,70,90,280$ & 1995 & 24,160 \\
\hline 2006 & $24,80,120$ & 2006 & 24 & 1996 & $24,80,120$ \\
\hline 2007 & 24,120 & 2007 & 24,170 & 1997 & $24,80,200$ \\
\hline 2008 & 24,320 & 2008 & 24,300 & 1998 & $24,70,100,130$ \\
\hline 2009 & 24,250 & 2009 & 24,130 & 1999 & $24,70,90,130$ \\
\hline \multicolumn{6}{|c|}{ T5 Instant FWI (18:00-19:00 at $1 \mathrm{~Hz}, n=3600)$} \\
\hline 2009:07:15 & $100,130,170,400$ & 2009:07:15 & 170,270 & 2011:5:15 & 160,270 \\
\hline 2009:07:16 & $60,140,300$ & 2009:07:16 & 100 & 2011:5:16 & 100 \\
\hline 2009:07:17 & $80,160,240,500$ & 2009:07:20 & 120,180 & 2011:5:17 & 120,180 \\
\hline 2009:07:18 & $70,140,400$ & 2009:07:21 & 140,270 & 2011:5:18 & $70,140,270$ \\
\hline 2009:07:19 & $70,240,550$ & 2009:07:23 & $90,180,240$ & 2011:5:19 & $90,160,220$ \\
\hline 2009:07:20 & $80,120180,300$ & 2009:07:24 & $80,140,260,540$ & 2011:5:20 & $70,140,260$ \\
\hline 2009:07:21 & 120,150 & 2009:07:25 & $80,120,340$ & 2011:5:21 & $70,140,340$ \\
\hline 2009:07:22 & 140,300 & 2009:07:26 & 100,280 & 2011:5:22 & 100,170 \\
\hline 2009:07:23 & $70,180,250$ & 2009:07:27 & $100,180,240,600$ & 2011:5:23 & 160,250 \\
\hline 2009:07:24 & $60,110,170230$ & & & 2011:5:24: & $100,160,230$ \\
\hline
\end{tabular}

forcing is highly predictable. Although synoptic scale spectral peaks in fire weather measures are weaker, predictions at that scale have useful skill (e.g., Jones et al., 2010). Indeed, it is the extremes that are important to fire activity. While variability at turbulent scales may be important to firefighter safety at critical fire behavior thresholds (where there is a non-linear response between wind speed and fire spread) it is unlikely to be predictable by numerical methods but could perhaps be represented statistically. The predictive skill of low frequency variability is likely insufficient to inform seasonal fire management decision making (where the cost of being wrong is high) but it is important to understand the effect of low frequency variability on long term fire activity and resource requirements.
Our purpose in using spectral analysis in this study was to develop an illustrative example; more rigorous spatio-temporal analyses are needed to characterize spatial-temporal patterns in the FWI as well as other meteorological measures, their spectral power, connections with fire activity and possible teleconnections between low frequency MDC and climate oscillations. For example, Magnussen and Taylor (2012b) examined correlation in peaks in weekly fire occurrences and area burned in each response center and province across Canada to estimate the likelihood of simultaneous peaks in fire activity in different regions. Applying clustering analysis to $>20$ year time series of daily FWI observations from 169 weather stations station across BC, Hrdlickova et al. (2008) found 7 spatio-temporal clusters of 
stations; these clusters represent regions of similar fire weather that can inform forecasting and preparedness planning.

\section{FIRE ACTIVITY ACROSS SCALES}

Wildland fires can be ignited in a few organic fuel particles by a lighting strike or from a variety of human causes (e.g., spark, glowing cigarette, friction, and electric arc) and will continue to spread between fuel particles as long as sufficient heat continues to be produced from their combustion to heat adjacent particles to ignition temperature (Sullivan, 2017). As a fire continues to spread and grow from a point source, it encounters and is influenced by variation in fuels, topography, and weather. Among these factors, weather is the most temporally variable "top down" driver of wildfire activity across scales, influencing the number of ignitions, fire spread and intensity, fire size and, area burned, and fire frequency from minutes to centuries. It is important to note that of the fire processes and the fire regime characteristics shown in Figure 6, only ignition is independent - fire spread and intensity, fire size and duration, area burned, and fire frequency measures are conditional on or a compound of lower level processes (Taylor et al., 2013). In the following section we briefly examine weather and climate influences on fire activity at some of these scales.

\section{Weather and Climate Influences}

\section{Turbulence}

Albini (1982) observed rapid response of fire spread to nonsteady wind in laboratory fires. There are few quantitative studies of fire behavior at fine scales in nature. In a series of nine intensively studied crown fires in the International Crown Fire Experiment, Taylor et al. (2004) observed substantial variation in fire spread in situ in the order of minutes that was also expressed in changes from passive to active crown fire behavior that they attributed to variation in wind speed around the threshold for crown fire initiation (Van Wagner, 1977b). They suggested that the phenomena of intermediate crown fire is due in part to turbulent gusts at the scale of $10 \mathrm{~s}$ meters and minutes. Fine scale variability in crown scorch and bark char height observed following surface fires that is due to varying fire intensity may be partly attributed to turbulence.

\section{Diurnal Variability}

The moisture content of live and dead shrub and tree foliage (Pook and Gill, 1993; Page et al., 2013) and forest floor litter (Beck and Armitage, 2001) typically decreases from a pre-dawn maxima to a late-afternoon minima. This follows from a similar diurnal trend in decreasing relative humidity during the day (Feidas et al., 2002) and an inverse diurnal trend in temperature, wind speed, and vapor pressure deficit (Beck and Trevitt, 1989; Barthelmie et al., 1996). Diurnal variation in fine fuel moisture is reflected in the probability of fire ignition over the day in field experiments (Beall, 1934) and in the number of fires reported over a $24 \mathrm{~h}$ period (Magnussen and Taylor, 2012a) which typically peak in late afternoon. Fire spread and intensity can vary greatly over the diurnal cycle (Beck et al., 2002) although direct measures of fire behavior and growth over a full daily cycle are scarce. However, diurnal variation in smoke emissions and fire radiative power is well documented through remote sensing methods (e.g., Prins et al., 1998; Giglio, 2007; Roberts et al., 2009; Andela et al., 2015).

Meso-scale turbulence resulting from convective heating producing thunderstorms or upslope or onshore winds in the day and down slope and offshore winds in the evening can result in strong increases in wind speed with shifting direction.

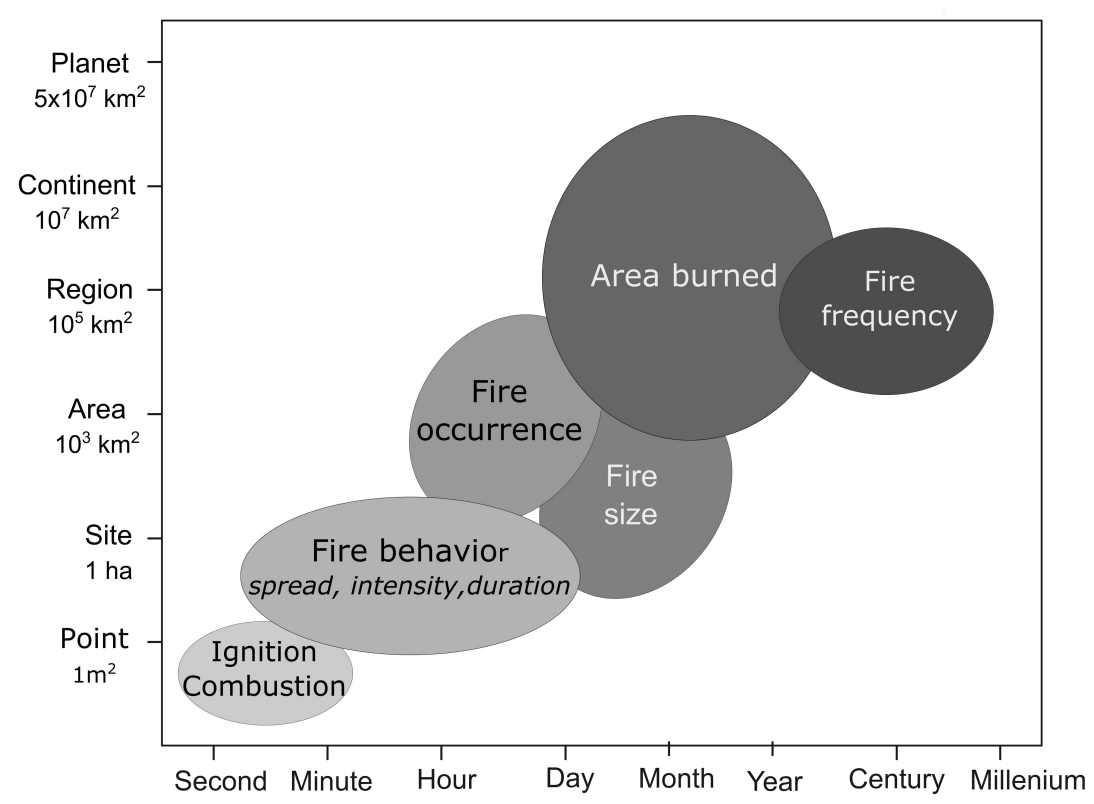

FIGURE 6 | Fire processes are compounded over temporal and spatial scales in an inverse cascade. Redrawn from Taylor et al. (2013). 
Downbursts from a thunderstorm (in part produced by the heat of the fire) channeled by topography contributed to rapid downslope spread of the Dude Fire and the entrapment and loss of 6 firefighters (Goens and Andrews, 1998).

Synoptic scale variability in the number of fire occurrences ${ }^{2}$ per day across British Columbia (Magnussen and Taylor, 2012a; Nadeem et al., 2019) and the daily number of active fires in the western United States (Freeborn et al., 2015) are strongly related to day to day variation in fuel moisture and fire danger measures. Synoptic level influences on daily burned area are evident in data on daily FWI and daily MODIS hotspot detects in (Field, 2020) data characterizing a fire complex of over $1000 \mathrm{~km}^{2}$ which burned over a period of 2 months in the record breaking 2017 fire season in British Columbia. Blocking ridges resulting in extended rain-free drying periods have been connected to increases in area burned (Skinner et al., 2000, 2002; Macias Fauria and Johnson, 2007) while upper ridge breakdowns are associated with increases in lightning fires (Macias Fauria and Johnson, 2006) and extreme fire behavior (Nimchuk, 1983) in western North America.

\section{Intraseasonal Variability}

Lightning intensity in the western United States has been linked to the intra-annual Madden Julian cycle (Abatzoglou and Brown, 2009). The moisture content of live and dead foliage varies seasonally (Blackmarr and Flanner, 1968; Gary, 1971); fuel ignitability (Beall, 1934) and increased fire spread rates are associated with plant senescence and decreasing fuel moisture (Cruz et al., 2015).

\section{Annual Variability}

Abatzoglou and Kolden (2013) found that annual area burned was significantly correlated with monthly values of several indicators of drought including the Energy Release Component and Buildup Index of the United States National Fire Danger Rating System, and the DMC and DC of the FWI System in predominantly temperate forests in the western United States. At a global scale, annual area burned was correlated with FWI and Cumulative Water Deficit during the fire season, particularly in mesic forested regions; burned area was more strongly correlated with precipitation in the previous $14-25$ months in nonforested regions (Abatzoglou et al., 2018). Yang et al. (2014) note that monthly area burned peaks in January and February in equatorial latitudes moving toward May-August at mid-high northern latitudes and to December-January at southern midhigh latitudes.

Inter-annual and decadal scale variation in fire occurrence has been associated with the PDO (Hessl et al., 2004) and annual area burned with ENSO - PDO interrelationships in northwestern North America Meyn et al. (2010); Mason et al. (2017) have also connected ENSO to fire potential in the continental United States. Lagged effects on ENSO on fire in the southern hemisphere are attributed in part to the effects of variable precipitation on grass fuel production (Harris et al., 2008). Chen et al. (2017) provide a comprehensive review of teleconnections between

\footnotetext{
${ }^{2}$ We distinguish the process of ignition of a small number of fuel particles resulting in an individual fire, from the occurrence of a number or population of fires in a broader geographic area.
}

ENSO and fire activity in different tropical regions. Regional anomalies in fire activity in response to ENSO vary from month to month, beginning in January/February in equatorial latitudes and migrating poleward through the year, and are mediated by differences in vegetation. In Canada, the AMO was also positively correlated with national annual time series of very large ( $\geq 10000 \mathrm{ha}$ ), wildfire-related evacuations, and fire suppression expenditures (Beverly et al., 2011).

Centennial to millennial scale variation in fire activity has been attributed to various factors, including effects of climate on vegetation and fuel availability. For example, millenial scale variation in fire during the last glacial interval is attributed to Dansgaard-Oeschger events (Daniau et al., 2007) and other climatic events like the Younger Dryas (Marlon et al., 2009). Daniau et al. (2013) also observed orbital scale variation in fire in southern Africa associated with Milankovitch cycles and grassland dynamics. In the present interglacial period, variations in seasonal and latitudinal insolation, extent of the northern hemisphere ice sheet and southern hemisphere ice caps, sea surface temperatures, atmospheric concentrations of $\mathrm{CO}_{2}$ and dust, clouds, and human actions have variously influenced global-regional atmospheric circulation, vegetation and wildfire occurrence (Power et al., 2008). For example, in Europe, North Atlantic ice rafting events or Bond cold cycles may have had a climatic pacing influence on fire activity with a periodicity of $\sim 1500$ years in the last glacial-interglacial transition and during the Holocene (Turner et al., 2008; Florescu et al., 2019).

\section{Geographical Variation}

The scales of atmospheric influence on fire activity outlined above are likely most applicable to mid to high latitudes that are characterized by complex low and high pressure systems that migrate under the influence of generally westerly winds in the troposphere (Barry and Chorley, 2009), leading to substantial synoptic scale variation in temperature, precipitation, humidity and wind speed in the fire season. In the southern hemisphere, Reeder et al. (2015) show seasonal patterns in mean Rossby wave breaking frequency at mid to high latitudes associated with anticyclones. The pattern proceeds easterly affecting different continental land masses differently in the austral spring, summer and fall. In southern Australia, anticyclones in austral summer result in a very dry northerly or northwesterly flow of air from the interior of the continent that are followed by cold fronts with strong southerlies or southwesterly winds; most severe fires in southern Australia have be affected by cold fronts (Reeder et al., 2015). Fire activity in Southern South America is related to the latitudinal position and intensity of the South Pacific High (SPH) that blocks southern south westerly winds and zonal flow of precipitation; the SPH shifts poleward in summer and is influenced at the interannual scale primarily by the pattern of the Antarctic Oscillation and secondarily by ENSO variability (Holz et al., 2012).

There is much less intra annual variation in temperature in the tropics at the surface and between air masses. Tropical weather is dominated by convective features of different scales such as cyclones and the InterTropical convergence zone of easterly flow; variation in precipitation and wind speed are likely 
more significant to fire activity. Although synoptic scale weather occurs in the tropics (Laing and Evans, 2015) many authors have highlighted the effect of ENSO on annual fire activity. Chen et al. (2017) provide a comprehensive review of teleconnections between ENSO and fire activity in different tropical regions. Regional anomalies in fire activity in response to ENSO vary from month to month, beginning in January/February in equatorial latitudes and migrating poleward through the year, and are mediated by differences in vegetation.

The relative contribution of subhourly to interannual scales of atmospheric variability to variation in fire weather and fire activity in different regions of the world would be an interesting area for further investigation. For example, in the United States, Mason et al. (2017) found that anomalies in the Buildup Index (BI) attributable to a modulated annual cycle (MAC) were largest in the western United States and in Florida, while BI anomalies attributable to ENSO were largest in the northwest and southeast United States Anomalies attributed to the MAC were approximately double those attributable to El Nino.

At a global scale, the asynchrony in monthly area burned peaks in northern mid and high latitudes and southern high latitudes (Yang et al., 2014) has allowed for increased sharing of fire management resources north-south and south-north in extreme fire years.

\section{Ecological Impacts of Fire}

Variation in fire activity may have second order ecological impacts across scales through "bottom up" interactions between fire, ecological features and processes and feedbacks (Heyerdahl et al., 2001; Holling, 2001). Varying weather, terrain, and vegetation results in varying fire behavior and severity within individual fire events (Catchpole, 2002; Hammill and Bradstock, 2009; Povak et al., 2020). Subhourly, diurnal, and synoptic scale variation in fire weather (including shifting wind direction) within the duration of an individual fire contributes to variation in fire intensity and spread direction within fires at spatial scales from meters to kilometers. Variation in fire intensity influences variability in fire-induced plant mortality (Etchells et al., 2020), post-fire residual stand structure, residual woody debris and surface organic matter (Miyanishi and Johnson, 2002), while variation in spread direction and intensity influence the prevalence of unburned patches within large fires (Andison and McCleary, 2014), and the fractal and fuzzy nature of fire perimeters (McAlpine and Wotton, 1993). The number of fire spread events and the time to extinguishment that influence fire size (Wang et al., 2020) are likely influenced by the occurrence of strong winds and fire ending precipitation events (Wiitala and Carlton, 1994) at meso to synoptic scales. Variation in the pattern of fire severity and fire size further influences the recruitment of plants (Etchells et al., 2020) and the diversity of post-fire insect, bird (Sitters et al., 2015) and other small animal communities (Banks et al., 2011). Seasonal variation in fire weather influences the size and severity of fires in a landscape (Perrakis and Agee, 2006; Russell-Smith and Edwards, 2006); interannual variation in burned area, primarily due to weather (Abatzoglou and Kolden, 2013) influences the species composition and age structure of vegetation in the landscape
(Andison, 1998), which in turn influences populations of many species, including large browsing animals such as elk (White et al., 1998). Millenial scale variation in climate and fire activity may also have affected the prevalence of grasses or woody trees in savanna biomes (Bond et al., 2003).

\section{FIRE MANAGEMENT DECISION SPACES}

Wildfire managers have the challenging job of preventing, preparing for, detecting, prioritizing and responding to fires threatening values in a dynamic environment where fire occurrence and/or fire behavior are stochastic processes, varying from minute-to-minute, hour-to-hour, day-to-day, week-toweek, and year- to-year with considerable uncertainty. Decisions taken range from individual incident to national level actions, where options are often constrained by limited access to fire locations, information, and resources, and where there may be multiple and conflicting demands and objectives. Systematic fire suppression began in North America in the late 1800s; wildfire management agencies in North America (and elsewhere) have subsequently developed organizational structures to acquire, position, allocate, and deploy resources to manage fires in this highly dynamic environment. Fire management decision making thus encompasses strategic, operational and tactical components (Taylor et al., 2013; Martell, 2015) including:

(1) Setting strategic objectives and policies, and determining the long-term requirements for resources (personnel and equipment) and where they should be based.

(2) Operational decisions through the fire season regarding the state of preparedness or organizational readiness, and the allocation of resources to particular geographic regions or fire incidents depending on the current and expected fire load and priorities.

(3) Tactical decisions regarding the deployment of resources to, and utilization of resources on managing active fires.

In this section we investigate, present, and discuss an analysis of fire management decision spaces in Canada and their relationship to temporal and spatial scales of fire weather and activity.

\section{Survey Methods}

During 2010 we carried out a set of structured interviews with approximately 20 staff of the 12 Canadian provincial and territorial wildfire management agencies, Parks Canada, and the Canadian Interagency Forest Fire Centre regarding fire management planning and decision making processes that were used in each agency. This was done to inform the development of a national resource forecasting system (Taylor et al., 2011). Our objective was to describe the decision spaces comprising preparedness and response functions, in order to define a structure for the forecasting model. A decision space is circumscribed by the range of options or choices and the range authority or responsibility that an agent has to make decisions about, or influence a range of functions and resources (Bossert, 
1998; Klein et al., 2009). These interviews and a subsequent literature review ${ }^{3}$ led to describing a number of types of decisions and mapping the fire management decision spaces in a spatiotemporal framework. The conceptual model was further refined through a number of presentations to the fire management agencies regarding the resource forecasting model, discussions with senior fire managers and researchers about decision making processes ${ }^{4}$ and our experience with providing fire forecasting and planning support to the BC Wildfire Service in several wildfire seasons over the past decade.

\section{Results}

In Canada, fire management is decentralized among 13 autonomous provincial and territorial agencies that have the primary responsibility for natural resource management in the Canadian federation, with only one federal agency, Parks Canada, managing fire in national parks. Decision making authority flows from legislation; in the province of British Columbia for example, the Wildfire Act provides direction. Supply chains are organized in order that appropriate resources (fire crews, aircraft and other equipment) based at hundreds of locations, can be dispatched from about 50 response centers to approximately 7500 fires annually across an area of about $10,000,000 \mathrm{~km}^{2}$ of managed forest as required to meet objectives. Our survey identified about 20 broad types of plans and decisions (Table A1) which were mapped to 16 decision spaces within 4-5 administrative levels from the national to incident level with a geographic span of $10,000,000-0.01 \mathrm{~km}^{2}$ and 6 time spans from decades to minutes that comprise the decision hierarchy. The influential variables and range of options or range of functions in a decision space have a similar spatiotemporal resolution, and the decisions associated with any particular space are compatible with the decisions taken in adjacent levels (Martell, 2001). The decision types listed in Appendix A1, and the spaces mapped as an $\mathrm{N} 2$ chart in Figure 7 are typical of the fire agencies in the Canadian provinces of British Columbia, Ontario and Quebec. These are briefly summarize in the following paragraphs, where the number and letters correspond to the grid location in Figure 7.

(1) National. In Canada, the Canadian Interagency Forest Fire Centre (CIFFC) and Parks Canada are the only fire agencies with a national geographic scope, (where CIFFC has a similar function to NIFC in the United States). An inter-agency Mutual Aid and Resource Sharing Agreement guides CIFFC activities; these include: (A) establishing exchange standards and other protocols; (B) coordinating national training courses on an annual basis, and most importantly, (C) coordinating the voluntary exchange of resources between Canadian agencies (and exchanges between Canada and other countries) when one or more of the 13 are experiencing a high fire load and

\footnotetext{
${ }^{3}$ Taylor et al. (2011). Review and discussion of fire management resource demand and capacity planning models. Unpublished file report.

${ }^{4}$ R. McAlpine and C. McFayden, Ontario Ministry of Natural Resources, Personal communications.
}

requirement for resources, and one or more agencies have low fire activity and excess resource capacity. High fire load may include large and prolonged incidents which de facto require national level resources. The duration of resource exchanges varies for aircraft, personnel, and equipment; personnel exchanges typically extend over 18 days. Resource exchanges depend on the expected fire load (number of new and active fires of varying complexity) and a relatively low likelihood of the cooccurrence of peaks in fire activity between two or more agencies (Magnussen and Taylor, 2012b) in a planning period, stemming from spatio-temporal separation in peak fire weather at a national scale.

(2) Provincial. As noted earlier, the primary authority for wildfire management in Canada stems from provincial legislation. Provincial/territorial decision making typically includes (A) setting strategic direction, permanent staffing, multi-year contracting for services such as airtankers, purchasing equipment and/or aircraft, and base location to meet level of protection objectives, which may include a target annual area burned limit (B) annual budgeting, seasonal staffing and training, seasonal contracting for services, and resource basing depending on the annual expectation of the number of fires of different complexity (C) importing or exporting of resources from/to other jurisdictions during the fire season, depending on the expected fire load (number of new and active fires of varying complexity) in a (typically 14 day) planning period. (D) in large provinces, reallocation of resources between regional response centers depending on the current and expected fire load in a planning period, including to high priority fires (E) daily prepositioning of provincially managed resources such as aircraft, depending on the expected number of new fire starts exceeding ground resources that day $(\mathrm{F})$ dispatching provincially managed resources such as aircraft to new fires in realtime, depending on their expected near term fire growth and values at risk.

(3) Response center. In larger provinces in Canada (Ontario, British Columbia, Quebec) resources are allocated at a regional scale from facilities which we refer to here as response centers. Decisions at this level typically include (C) medium and short term contracting for resources depending on the expected load of fires of different complexity over approximately 3-30 planning periods (D) 1-3 day preparedness levels, and prepositioning of resources depending in part on the expected number, intensity and location of new fire starts (E) daily routing of detection aircraft, depending on the expected number, severity and location of new fire starts, and allocating resources to active fires depending on their complexity, expected growth and priority, (F) dispatching initial attack resources, depending on the expected near term growth of new fire starts and values at risk.

(4) Operating Base. Initial attack and sustained action crews are typically based at a number of locations within a response center. Decisions at this level include (D/E) 


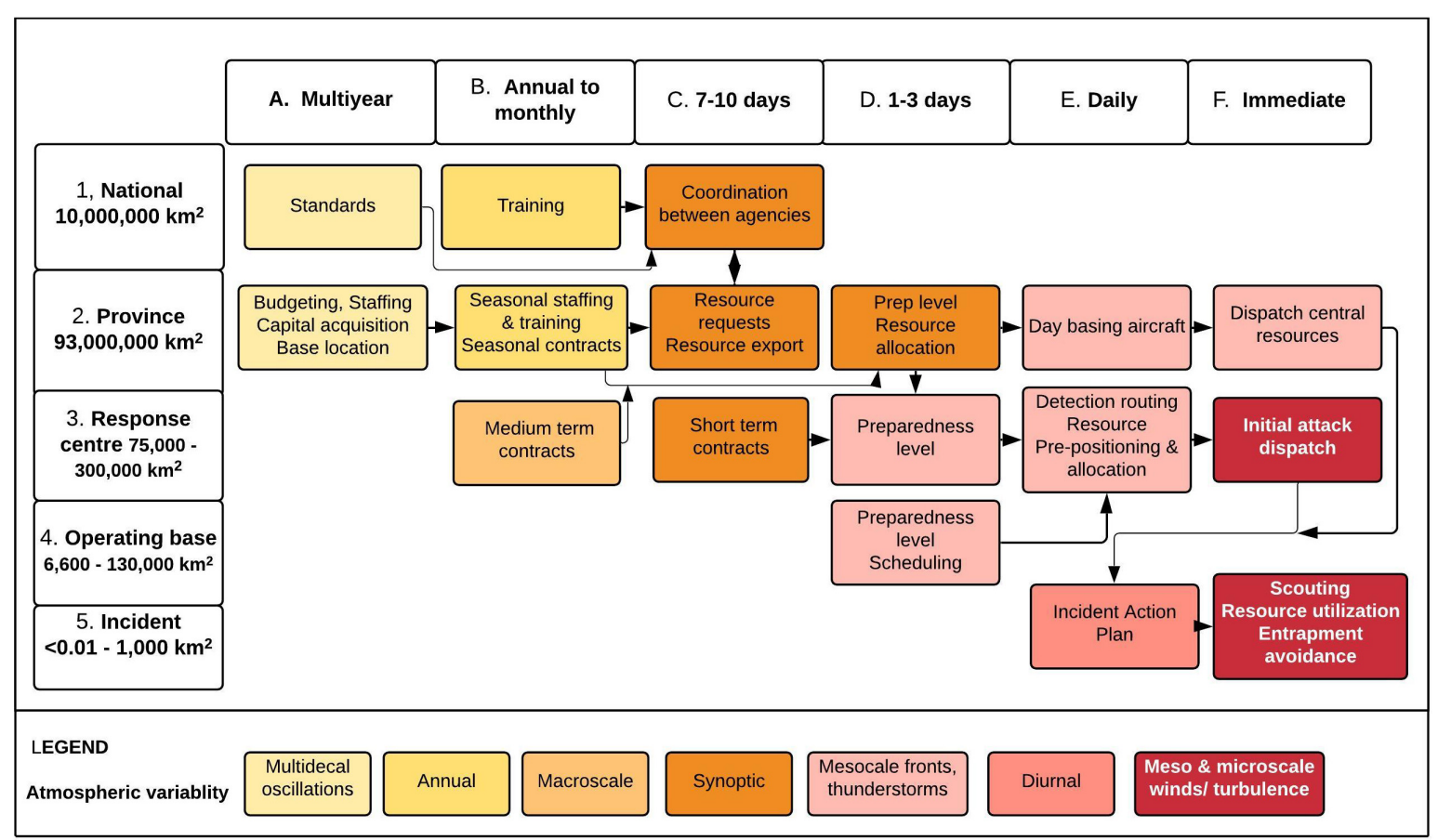

FIGURE 7| An N-2 chart of typical situation spaces in fire management decision making in the province of British Columbia, Canada, and influences of atmospheric variability.

establishing preparedness levels, opening temporary subbases, and scheduling crew availability, depending in part on the expected number, intensity and location of new fire starts.

(5) Incident (Fire). As in many other nations, Canada uses the Incident Command System, where (E) daily tactical objectives and resource deployment decisions are communicated in an Incident Action Plan, with reference to expected fire behavior and growth in the present and immediately following operational periods (typically a day). Decisions regarding (F) deployment and utilization of resources and plans for entrapment avoidance that are made throughout the day or operational period at the Division, Sector, Task Force, or Crew levels (depending on the complexity of the fire) are responsive to the immediate and expected weather and fire behavior conditions during the day. Actions such as a tactical withdrawl depend on changes in the immediate and expected fire intensity and spread over a period of minutes to hour.

\section{Summary}

Our analysis of decision making in the fire management supply chain (Martell, 2015) led to the mapping of sixteen decision or situation spaces, where the decisions in each space have quite clear temporal and spatial scope. We recognize that this hierarchical model is a simplification - while the flow of resources in the fire management supply chain is a forward cascade, information flow between organizational levels is more dynamic. However, the fire management hierarchical framework is nearly decomposable (Simon, 1974) into tractable spaces to address with particular decision problems. Rothermel (1980); Andrews (2006) also provided spatio-temporal frameworks for the development of fire management decision support systems; our model has a similar structure but is more granular and emphasizes decision making within the fire season.

Fire management agencies are fast-response organizations (Faraj and Xiao, 2006) that operate in conditions requiring rapid decision making, where the annual and daily fire load, and individual fire activity is highly dependent on forcing by climate and weather. Minas et al. (2012) observed that wildfire management is a kind of "hyper project" (Simpson, 2006), a special class of operations where a set of tasks and resource requirements interact with a dynamic, external pacing function - fire weather and fire activity. Decision or situation spaces are strongly connected to three elements of situational awareness (Endsley, 1988) - "the perception of the elements in the environment within a volume of time and space, the comprehension of their meaning and the projection of their status in the near future." The depth and scope of SA is an important factor in decision-making in a dynamic environment. SA is at the nexus of fire management decision spaces and fire weather scales. Similar to the treatment of climate and weather as "top down" controls on fire regimes (Gill and Taylor, 2009), weather and climate are top down controls on fire management, representing a pacing function that influences the tempo of fire activity and decision making. Fire management decision spaces are shaped in part, by the predictability of temporal and spatial fire weather patterns, and the uncertainty of associated fire activity at these 
scales. It is noteworthy that as the time scale decreases on critical days, fire activity can increase sharply in a hours or minutes in response to rapid changes in weather, the time for decision making is compressed and weather and predictive models have limited utility; quick intuitive judgements may supersede slower rational thought processes (Alexander et al., 2015). In this study we did not examine the factors influencing the geographic span of decision spaces which, in addition to patterns of weather and fire occurrence, many include historical factors (e.g., national, provincial boundaries) travel time and coverage concerns for operating bases, settlement patterns and values.

\section{SYNTHESIS}

This special issue of Frontiers In Environmental Science addressed the question "Climate, Land Use and Fire - Can Models Inform Management?" Our study emphasizes the importance of scale in fire science and modeling. To paraphrase Levin (1992), scale unifies fire physics and fire ecology, and connects basic and applied research.
"Applied challenges ... require the interfacing of phenomena that occur on very different scales of space, time, and ... organization. Furthermore, there is no single natural scale at which ... phenomena should be studied; systems generally show characteristic variability on a range of spatial, temporal, and organizational scales" (Levin, 1992).

The purpose of this paper was to develop a conceptual framework demonstrating that atmospheric, wildfire, and fire management process are complex interacting physical, ecological and socio-economic systems connected by scale. We propose that the cascade of kinetic energy through atmospheric scales that is expressed in part in fire weather conditions, is reflected in an inverse cascade of chemical energy released through fire processes, and further shapes a forward cascade of fire management activities and resources (Figure 8). Climate and weather are a pacing function on fire activity and management across all scales.

Turner et al. (1989) outlined a four step procedure to make predictions across scales (1) identify the spatial and temporal scales of the process (2) understand how the factors controlling

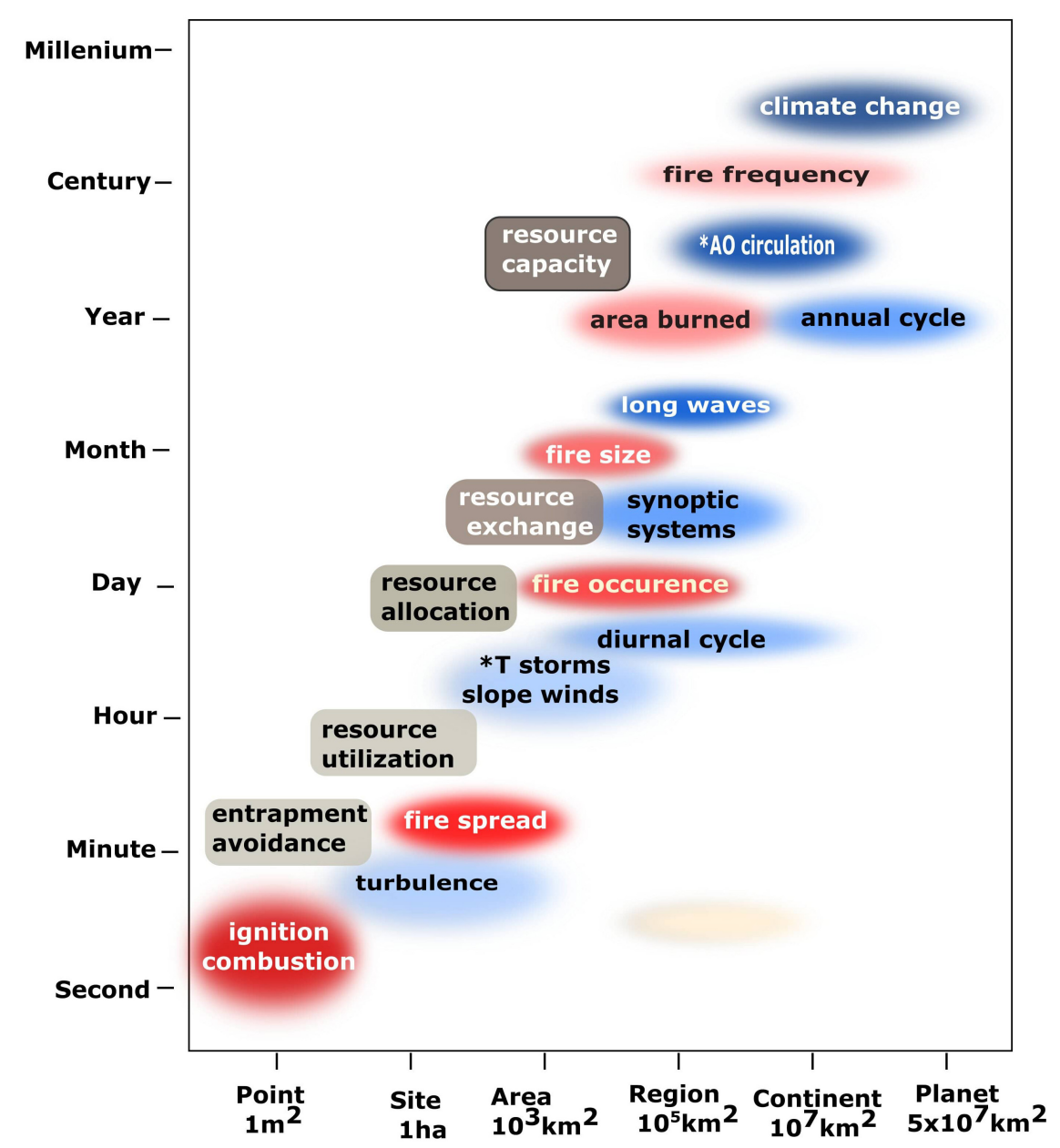

FIGURE 8| The atmospheric energy cascade (blue ovals) shapes an inverse cascade of fire processes (red ovals) and the fire management supply chain (gray rectangles). Adapted from Simard (1991); Holling (2001), Taylor et al. (2013). *AO = Atmospheric Oceanic, T-storm = thunderstorm. 
the process vary with scale (3) develop methods to translate predictions from one scale to the other, and (4) test predictions across multiple scales. This paper is an early exploration of the first two steps in this sequence that may help frame models that inform fire management. Further work is needed to bridge scales for particular management questions. For example, the impact of climate change on fire activity is the most important challenge for fire managers in this century. The net gain in energy represented by climate forcing will influence atmospheric processes and fire activity at a number of scales. Macias Fauria et al. (2011) suggest that predicting climate change effects on wildfires requires understanding and unification of climate and the underlying fire behavior processes across scales. While there has been a significant effort to understand the effects of climate change on fire weather (Fargeon et al., 2020) and broad scale measures of fire activity such as annual area burned (Flannigan et al., 2005), relatively few fire-climate change studies are linked to fire management decision making (Wotton et al., 2017). Methods are needed to translate climate projections to fire management decision scales.

\section{REFERENCES}

Abatzoglou, J. T., and Brown, T. J. (2009). Influence of the Madden-Julian oscillation on summertime cloud-to-ground lightning activity over the continental United States. Mon. Weather Rev. 137, 3596-3601. doi: 10.1175/ 2009mwr3019.1

Abatzoglou, J. T., and Kolden, C. A. (2013). Relationships between climate and macroscale area burned in the western United States. Int. J. Wildland Fire 22, 1003-1020. doi: 10.1071/wf13019

Abatzoglou, J. T., Williams, A., Boschetti, L., Zubkova, M., and Kolden, C. A. (2018). Global patterns of interannual climate-fire relationships. Glob. Change Biol. 24, 5164-5175. doi: 10.1111/gcb.14405

Albini, F. A. (1982). Response of free-burning fires to nonsteady wind. Combust. Sci. Technol. 29, 225-241. doi: 10.1080/00102208208923599

Alexander, M. E., Cruz, M. G., and Taylor, S. W. (2019). “Crown scorch height," in Encyclopedia of Wildfires and Wildland-Urban Interface (WUI) Fires, ed. S. L. Manzello (Berlin: Springer International Publishing).

Alexander, M. E., and De Groot, W. J. (1988). Fire Behavior in Jack Pine Stands: As Related to the Canadian Forest Fire Weather Index (FWI) System. Edmonton, AB: Northern Forestry Centre.

Alexander, M. E., Taylor, S. W., and Page, W. G. (2015). "Wildland firefighter safety and fire behavior prediction on the fireline," in Proceedings of the 13th Annual Wildland Fire Safety Summit \& 4th Human Dimensions of Wildland Fire Conference April 20-24, 2015, Boise, ID.

Andela, N., Kaiser, J. W., van der Werf, G. R., and Wooster, M. J. (2015). New fire diurnal cycle characterizations to improve fire radiative energy assessments made from low-Earth orbit satellites sampling. Atmos. Chem. Phys. 15, 88318846. doi: 10.5194/acp-15-8831-2015

Andison, D. W. (1998). Temporal patterns of age-class distributions on foothills landscapes in Alberta. Ecography 21, 543-550. doi: 10.1111/j.1600-0587.1998. tb00446.x

Andison, D. W., and McCleary, K. (2014). Detecting regional differences in withinwildfire burn patterns in western boreal Canada. For. Chron. 90, 59-69. doi: 10.5558/tfc2014-011

Andrews, P. L. (2006). "A temporal and spatial framework for development and application of wildland fire decision support systems," in Proceedings of the Vth International Conference on Forest Fire Research, Figueira da Foz.

Andrews, P. L. (2014). Current status and future needs of the BehavePlus Fire Modeling System. Int. J. Wildland Fire 23, 21-33. doi: 10.1071/ wf12167

\section{DATA AVAILABILITY STATEMENT}

The datasets generated for this study are available on request to the corresponding author.

\section{AUTHOR CONTRIBUTIONS}

SWT conceived the study, carried out the analysis, and wrote the manuscript.

\section{ACKNOWLEDGMENTS}

Thanks are extended to Z. Nemic for retrieving archival flux tower data, and to the BC Wildfire Service and Saskatchewan Environment for fire weather data, to $\mathrm{M}$. Alexander for pointing to the references for Figure 4, and to two reviewers who greatly improved the manuscript. K. Omendje assisted with data preparation. Discussions with R. McAlpine and C. McFayden helped to refine the map of decision spaces.

Anonymous (1958). Areas of Climatic Regions and their Distribution by Provinces and Territories (map). Atlas of Canada, 3rd Edn. (Ottawa: Department of Mines and Technical Surveys).

Banks, S. C., Dujardin, M., Mcburney, L., Blair, D., Barker, M., and Lindenmayer, D. B. (2011). Starting points for small mammal population recovery after wildfire: recolonisation or residual populations? Oikos 120, 26-37. doi: 10.1111/ j.1600-0706.2010.18765.x

Barbero, R., Abatzoglou, J. T., Pimont, F., Ruffault, J., and Curt, T. (2020). Attributing increases in fire weather to anthropogenic climate change over France. Front. Earth Sci. 8:104. doi: 10.3389/feart.2020.00104

Barry, R. G., and Chorley, R. J. (2009). Atmosphere, Weather and Climate. London: Routledge.

Barthelmie, R. J., Branko, G., and Pryor, S. C. (1996). Observations and simulations of diurnal cycles of near-surface wind speed's over land and sea. J. Geophys. Res. Atmos. 101, 21327-21337. doi: 10.1029/96jd01520

Beall, H. W. (1934). Diurnal and seasonal fluctuation of fire hazard in pine forests. For. Chron. 10, 209-225. doi: 10.5558/tfc10209-4

Beck, J. A., Alexander, M. E., Harvey, S. D., and Beaver, A. K. (2002). Forecasting diurnal variations in fire intensity to enhance wildland firefighter safety. Int. J. Wildland Fire 11, 173-182. doi: 10.1071/wf02002

Beck, J. A., and Armitage, O. B. (2001). "Diurnal fine fuel moisture characteristics at a northern latitude," in Proceedings of the 22nd Tall Timbers Fire Ecology Conference: Fire in Temperate, Boreal, and Montane Ecosystems, Kananaskis, $\mathrm{AB}, 15-18$.

Beck, J. A., and Trevitt, A. C. F. (1989). Forecasting diurnal variations in meteorological parameters for predicting fire behaviour. Can. J. For. Res. 19, 791-797. doi: 10.1139/x89-120

Beverly, J. L., Flannigan, M. D., Stocks, B. J., and Bothwell, P. (2011). The association between Northern Hemisphere climate patterns and interannual variability in Canadian wildfire activity. Can. J. For. Res. 41, 2193-2201. doi: 10.1139/x11-131

Blackmarr, W. H., and Flanner, W. B. (1968). Seasonal and Diurnal Variation in Moisture Content of Six Species of Pocosin Shrubs. Washington, DC: US Department of Agriculture.

Bond, W. J., Midgley, G. F., and Woodward, F. I. (2003). The importance of low atmospheric CO2 and fire in promoting the spread of grasslands and savannas. Glob. Change Biol. 9, 973-982. doi: 10.1046/j.1365-2486.2003.00577.x

Bossert, T. (1998). Analyzing the decentralization of health systems in developing countries: decision space, innovation and performance. Soc. Sci. Med. 47, 1513-1527. doi: 10.1016/s0277-9536(98)00234-2 
Bowman, D. M., Balch, J. K., Artaxo, P., Bond, W. J., Jean, M. C., Mark, A. C., et al. (2009). Fire in the earth system. Science 324, 481-484.

Brocklebank, J. C., Dickey, D. A., and Choi, B. (2018). SAS for Forecasting Time Series. Cary, NC: SAS institute.

Brown, M., Black, T. A., Nesic, Z., Foord, V. N., Fredeen, A. L., Spittlehouse, D. L., et al. (2012). The carbon balance of two lodgepole pine stands recovering from mountain pine beetle attack in British Columbia. Agric. For. Meteorol. 153, 82-93. doi: 10.1016/j.agrformet.2011.07.010

Catchpole, W. (2002). "Fire properties and burn patterns in heterogeneous landscapes," in Flammable Australia: The Fire Regimes and Biodiversity of a Continent, eds R. A. Bradstock, J. E. Williams, and A. M. Gill (Cambridge: Cambridge University Press), 49-76.

Chen, Y., Morton, D. C., Andela, N., Van Der Werf, G. R., Giglio, L., and Randerson, J. T. (2017). A pan-tropical cascade of fire driven by El Niño/Southern Oscillation. Nat. Clim. Change 7, 906-911. doi: 10.1038/ s41558-017-0014-8

CIFFC Glossary Task Team and Training Working Group (2017). Canadian Wildland Fire Management Glossary Canadian Interagency Forest Fire Centre. Winnipeg: CIFFC.

Corringham, T. W., Westerling, A. L., and Morehouse, B. J. (2008). Exploring use of climate information in wildland fire management: a decision calendar study. J. For. 106, 71-77.

Cruz, M. G., Gould, J. S., Kidnie, S., Bessell, R., Nichols, D., and Slijepcevic, A. (2015). Effects of curing on grassfires: II. Effect of grass senescence on the rate of fire spread. Int. J. Wildland Fire 24, 838-848. doi: 10.1071/wf14146

Daniau, A.-L., Sánchez Goñi, M. F., Martinez, P., Urrego, D. H., BoutRoumazeilles, V., Desprat, S., et al. (2013). Orbital-scale climate forcing of grassland burning in southern Africa. Proc. Natl. Acad. Sci. U.S.A. 110, 50695073. doi: $10.1073 /$ pnas. 1214292110

Daniau, A. L., Sánchez-Goñi, M. F., Beaufort, L., Laggoun-Défarge, F., Loutre, M. F., and Duprat, J. (2007). Dansgaard-Oeschger climatic variability revealed by fire emissions in southwestern Iberia. Quat. Sci. Rev. 26, 1369-1383. doi 10.1016/j.quascirev.2007.02.005

Donovan, G. (2006). Determining the optimal mix of federal and contract fire crews: a case study from the Pacific Northwest. Ecol. Model. 194, 372-378. doi: 10.1016/j.ecolmodel.2005.10.043

Endsley, M. R. (1988). "Design and evaluation for situation awareness enhancement," in Proceedings of the Human Factors Society 32nd Annual Meeting, Santa Monica, CA.

Etchells, H., O’Donnell, A. J., McCaw, W. L., and Grierson, P. F. (2020). Fire severity impacts on tree mortality and post-fire recruitment in tall eucalypt forests of southwest Australia. For. Ecol. Manage. 459:117850. doi: 10.1016/j. foreco.2019.117850

Faraj, S., and Xiao, Y. (2006). Coordination in fast-response organizations. Manage. Sci. 52, 1155-1169. doi: $10.1287 / \mathrm{mnsc} 1060.0526$

Fargeon, H., Pimont, F., Martin-StPaul, N., Caceres, M., Ruffault, J., Barbero, R., et al. (2020). Projections of fire danger under climate change over France: where do the greatest uncertainties lie? Clim. Change 160, 479-493. doi: 10.1007/ s10584-019-02629-w

Feidas, H., Cartalis, C., and Lagouvardos, C. (2002). Temporal simulation of diurnal temperature and relative humidity evolution at a forested mountainous site in Attica, Greece. Int. J. Wildland Fire 11, 95-106. doi: 10.1071/ wf02019

Field, R. D. (2020). Evaluation of Global Fire Weather Database reanalysis and short-term forecast products. Nat. Hazards Earth Syst. Sci. 20, 1123-1147. doi: 10.5194/nhess-20-1123-2020

Field, R. D., Fernandes, K., Glover, K. C., Hansen, W. D., Rabinowicz, J., and Williams, A. P. (2018). Understanding the roles of fuels, climate and people in predicting fire: taking the long view. Pages Mag. 26:41. doi: 10.22498/pages. 26.1.41

Flannigan, M. D., Logan, K. A., Amiro, B. D., Skinner, W. R., and Stocks, B. J. (2005). Future area burned in Canada. Clim. Change 72, 1-16. doi: 10.1007/ s10584-005-5935-y

Florescu, G., Brown, K. J., Carter, V. A., Kuneš, P., Veski, S., and Feurdean, A. (2019). Holocene rapid climate changes and ice-rafting debris events reflected in high-resolution European charcoal records. Quat. Sci. Rev. 222:105877. doi: 10.1016/j.quascirev.2019.105877
Fluxnet Canada Team (2016). FLUXNET Canada Research Network - Canadian Carbon Program Data Collection, 1993-2014. Oak Ridge, TN: ORNL DAAC.

Forestry Canada Fire Danger Group (1992). Development and structure of the Canadian Forest Fire Behavior Prediction System. Technical Report ST-X-3. Ottawa: Forestry Canada.

Fraedrich, K., and Böttger, H. (1978). A wavenumber-frequency analysis of the $500 \mathrm{mb}$ geopotential at 50 N. J. Atmos. Sci. 35, 745-750. doi: 10.1175/15200469(1978)035<0745:AWFAOT>2.0.CO;2

Fraedrich, K., and Kietzig, E. (1983). Statistical analysis and wavenumberfrequency spectra of the $500 \mathrm{mb}$ geopotential along 50 S. J. Atmos. Sci. 40, 1037-1045. doi: 10.1175/1520-0469(1983)040<1037:SAAWFS >2.0.CO;2

Freeborn, P. H., Cochrane, M. A., and Jolly, W. M. (2015). Relationships between fire danger and the daily number and daily growth of active incidents burning in the northern Rocky Mountains, USA. Int. J. Wildland Fire 24, 900-910. doi: $10.1071 /$ wf14152

Fujita, T. T. (1981). Tornadoes and downbursts in the context of generalized planetary scales. J. Atmos. Sci. 38, 1511-1534. doi: 10.1175/1520-0469(1981) $038<1511$ :taditc $>2.0$. co 2

Gary, H. L. (1971). Seasonal and diurnal changes in moisture contents and water deficits of Engelmann spruce needles. Bot. Gaz. 132, 327-332. doi: 10.1086/ 336598

Giglio, L. (2007). Characterization of the tropical diurnal fire cycle using VIRS and MODIS observations. Remote Sens. Environ. 108, 407-421. doi: 10.1016/j.rse. 2006.11.018

Gill, L., and Taylor, A. H. (2009). Top-down and bottom-up controls on fire regimes along an elevational gradient on the east slope of the Sierra Nevada, California, USA. Fire Ecol. 5, 57-75. doi: 10.4996/fireecology.0503057

Girardin, M. P., and Wotton, B. M. (2009). Summer moisture and wildfire risks across Canada. J. Appl. Meteorol. Climatol. 48, 517-533. doi: 10.1175/ 2008jamc1996.1

Goens, D. W., and Andrews, P. L. (1998). "Weather and fire behavior factors related to the 1990 Dude Fire near Payson, AZ," in Proceedings, 2nd Symposium on Fire and Forest Meteorology, Boston, MA, 153-158.

Hammill, K. A., and Bradstock, R. A. (2009). Spatial patterns of fire behaviour in relation to weather, terrain and vegetation. Proc. R. Soc. Queensland 115, 129-135.

Hardy, C. C., and Hardy, C. E. (2007). Fire danger rating in the United States of America: an evolution since 1916. Int. J. Wildland Fire 16, 217-231. doi: $10.1071 /$ wf06076

Harris, S., Tapper, N., Packham, D., and Orlove, B. (2008). The relationship between the monsoonal summer rain and dry-season fire activity of northern Australia. Int. J. Wildland Fire 17, 674-684. doi: 10.1071/wf06160

Hessl, A. E., McKenzie, D., and Schellhaas, R. (2004). Drought and Pacific Decadal Oscillation linked to fire occurrence in the inland Pacific Northwest. Ecol. Appl. 14, 425-442. doi: 10.1890/03-5019

Heyerdahl, E. K., Brubaker, L. B., and Ageem, J. K. (2001). Spatial controls of historical fire regimes: a multiscale example from the interior west, USA. Ecology 82, 660-678. doi: 10.1890/0012-9658(2001)082 [0660:scohfr]2.0.co;2

Holling, C. S. (2001). Understanding the complexity of economic, ecological, and social systems. Ecosystems 4, 390-405. doi: 10.1007/s10021-001-0101-5

Holz, A., Kitzberger, T., Paritsis, J., and Veblen, T. T. (2012). Ecological and climatic controls of modern wildfire activity patterns across southwestern South America. Ecosphere 3, 1-25.

Hrdlickova, Z., Esterby, S., and Taylor, S. W. (2008). "Classification of regions with respect to fire risk," in Proceedings of the 19th Annual Conference of the International Environmetrics Society, Kelowna. doi: 10.1201/b16 199-2

Islam, K. M. S. (1998). Spatial Dynamic Queueing Models for the Daily Deployment of Airtankers for Forest Fire Control. Ph.D. dissertation, University of Toronto, Toronto.

Jain, P., Coogan, S. C., Subramanian, S. G., Crowley, M., Taylor, S., and Flannigan, M. D. (2020). A review of machine learning applications in wildfire science and management. Environ. Rev. arXiv preprintarXiv:2003.00646. doi: 10.1139/er2020-0019

Jones, C., Fujioka, F., and Carvalho, L. M. (2010). Forecast skill of synoptic conditions associated with Santa Ana winds in Southern California. Mon. Weather Rev. 138, 2253-2280. 
Kaplan, A. (2011). Sidebar 1.1: Patterns and Indices of Climate Variability," in Blunden, J., D. S. Arndt, and M. O. Baringer, State of the Climate in 2010" (2011). Publications, Agencies and Staff of the U.S. Department of Commerce. 51. Available online at: http://digitalcommons.unl.edu/usdeptcommercepub/ 516 (accessed September 15, 2020).

Klein, G. L., Pfaff, M. S., and Drury, J. L. (2009). "Supporting a robust decision space," in Proceedings of the 2009 AAAI Spring Symposium: Technosocial Predictive Analytics, Stanford, CA, 66-71.

Krishnamurthy, V. (2019). Predictability of weather and climate. Earth Space Sci. 6, 1043-1056.

Laing, A., and Evans, J. L. (2015). Introduction to Tropical Meteorology, 2nd Edn. Boulder, CO: University Corporation for Atmospheric Research.

Lawson, B. D., and Dalrymple, G. N. (1996). Ground-Truthing the Drought Code: Field Verification of Overwinter Recharge of Forest Floor Moisture. FRDA Report 268. Victoria: Canadian Forest Service.

Levin, S. A. (1992). The problem of pattern and scale in ecology: the Robert H. MacArthur award lecture. Ecology 73, 1943-1967. doi: 10.2307/19 41447

Li, Z., Li, Y., Bonsal, B., Manson, A. H., and Scaff, L. (2018). Combined impacts of ENSO and MJO on the 2015 growing season drought on the Canadian Prairies. Hydrol. Earth Syst. Sci. 22, 5057-5067. doi: 10.5194/hess-22-5057-2018

Lovejoy, S., and Schertzer, D. (2010). Towards a new synthesis for atmospheric dynamics: space-time cascades. Atmos. Res. 96, 1-52. doi: 10.1016/j.atmosres. 2010.01.004

Lovejoy, S., and Schertzer, D. (2012). Low frequency weather and the emergence of the climate. Extreme events and natural hazards: the complexity perspective. Geophys. Monogr. Ser. 196, 231-254. doi: 10.1029/2011gm001087

Macias Fauria, M., and Johnson, E. A. (2006). Large-scale climatic patterns control large lightning fire occurrence in Canada and Alaska forest regions. J. Geophys. Res. 111:G04008.

Macias Fauria, M., and Johnson, E. A. (2007). Climate and wildfires in the North American boreal forest. Philos. Trans. R. Soc. Lond. B Biol. Sci. 363, 2317-2329.

Macias Fauria, M., Michaletz, S. T., and Johnson, E. A. (2011). Predicting climate change effects on wildfires requires linking processes across scales. Wiley Interdiscip. Rev. Clim. Change 2, 99-112. doi: 10.1002/wcc.92

MacLellan, J. I., and Martell, D. L. (1996). Basing airtankers for forest fire control in Ontario. Oper. Res. 44, 662-838.

Magnussen, S., and Taylor, S. W. (2012a). Prediction of daily lightning- and humancaused fires in British Columbia. Int. J. Wildland Fire 21, 342-356. doi: 10.1071/ wf11088

Magnussen, S., and Taylor, S. W. (2012b). Inter-and intra-annual profiles of fire regimes in the managed forests of Canada and implications for resource sharing. Int. J. Wildland Fire 21, 328-341. doi: 10.1071/wf11026

Marlon, J. R., Bartlein, P. J., Walsh, M. K., Harrison, S. P., Brown, K. J., Edwards, M. E., et al. (2009). Wildfire responses to abrupt climate change in North America. Proc. Natl. Acad. Sci. U.S.A. 106, 2519-2524.

Martell, D. L. (2015). A review of recent forest and wildland fire management decision support systems research. Curr. For. Rep. 1, 128-137.

Martell, D. L. (2001). "Forest fire management," in Handbook of Operations Research in Natural Resources. International Series in Operations Research amp; Mana, Vol. 99, eds A. Weintraub, C. Romero, T. Bjørndal, R. Epstein, and J. Miranda (Boston, MA: Springer), 527-583. doi: 10.1016/b978-012386660-8/ 50017-9

Mason, S. A., Hamlington, P. E., Hamlington, B. D., Jolly, W., and Hoffman, C. M. (2017). Effects of climate oscillations on wildland fire potential in the continental United States. Geophys. Res. Let. 44, 7002-7010. doi: 10.1002/ 2017gl074111

McAlpine, R. S., and Wotton, B. M. (1993). The use of fractal dimension to improve wildland fire perimeter predictions. Can. J. For. Res. 23, 1073-1077. doi: $10.1139 / \mathrm{x} 93-137$

McLauchlan, K. K., Higuera, P. E., Miesel, J., Rogers, B. M., Jennifer, S., Alan, J. T., et al. (2020). Fire as a fundamental ecological process: research advances and frontiers. J. Ecol. 108, 2047-2069.

Meyn, A., Taylor, S. W., Flannigan, M. D., Thonicke, K., and Cramer, W. (2010). Relationship between fire, climate oscillations, and drought in British Columbia, Canada, 1920-2000. Glob. Change Biol. 16, 977-989. doi: 10.1111/j. 1365-2486.2009.02061.x
Minas, J., Hearne, J., and Handmer, J. (2012). A review of operations research methods applicable to wildfire management. Int. J. Wildland Fire 21, 189-196. doi: $10.1071 /$ wf10129

Miyanishi, K., and Johnson, E. A. (2002). Process and patterns of duff consumption in the mixedwood boreal forest. Can. J. For. Res. 32, 1285-1295. doi: 10.1139/ x02-051

Nadeem, K., Taylor, S. W., Woolford, D. G., and Dean, C. B. (2019). Mesoscale spatiotemporal predictive models of daily human-and lightningcaused wildland fire occurrence in British Columbia. Int. J. Wildland Fire. 29, 11-27. doi: 10.1071/wf19058

National Wildfire Coordinating Group [NWCG] (2019). NWCG Glossary of Wildland Fire (online). Available online at: https://www.nwcg.gov/glossary/a-z (accessed December 15, 2019).

Nimchuk, N. (1983). Wildfire Behavior Associated with Upper Ridge Breakdown. Edmonton, AB: Alberta Energy and Natural Resources.

Orlanski, I. (1975). A rational subdivision of scales for atmospheric processes. Bull. Am. Met. Soc. 56, 527-530.

Page, W. G., Jenkins, M. J., and Alexander, M. E. (2013). Foliar moisture content variations in lodgepole pine over the diurnal cycle during the red stage of mountain pine beetle attack. Environ. Model. Softw. 49, 98-102. doi: 10.1016/j. envsoft.2013.08.001

Palmer, T., and Hagedorn, R. (eds) (2006). Predictability of Weather and Climate. Cambridge: Cambridge University Press.

Perrakis, D. D. B., and Agee, J. K. (2006). Seasonal fire effects on mixed-conifer forest structure and ponderosa pine resin properties. Can. J. For. Res. 36, 238-254. doi: $10.1139 / \mathrm{x} 05-212$

Pook, E. W., and Gill, A. M. (1993). Variation of live and dead fine fuel moisture in Pinus radiata plantations of the Australian-Capital-Territory. Int. J. Wildland Fire 3, 155-168. doi: 10.1071/wf9930155

Povak, N. A., Kane, V. R., Collins, B. M., Lydersen, J. M., and Kane, J. T. (2020). Multi-scaled drivers of severity patterns vary across land ownerships for the 2013 Rim Fire, California. Landsc. Ecol. 35, 293-318. doi: 10.1007/s10980-01900947-z

Power, M. J., Marlon, J., Ortiz, N., Bartlein, P., Harrison, S. P., Mayle, F. E., et al. (2008). Changes in fire regimes since the Last Glacial Maximum: an assessment based on a global synthesis and analysis of charcoal data. Clim. Dyn. 30, 887-907.

Prins, E. M., Feltz, J. M., Menzel, W. P., and Ward, D. E. (1998). An overview of GOES-8 diurnal fire and smoke results for SCAR-B and 1995 fire season in South America. J. Geophys. Res. 103, 31821-31835. doi: 10.1029/98jd01720

Reeder, M. J., Spengler, T., and Musgrave, R. (2015). Rossby waves, extreme fronts, and wildfires in southeastern Australia. Geophys. Res. Letters 42, 2015-2023. doi: $10.1002 / 2015 \mathrm{gl} 063125$

Richardson, L. F. (1922). Weather Prediction by Numerical Processes. Cambridge: Cambridge University Press.

Roberts, G., Wooster, M. J., and Lagoudakis, E. (2009). Annual and diurnal African biomass burning temporal dynamics. Biogeosciences 6, 849-866. doi: 10.5194/ bg-6-849-2009

Rothermel, R. C. (1980). "Fire behavior systems for fire management," in Proceedings of the Sixth Conference on Fire and Forest Meteorology, Seattle, WA, $58-64$.

Russell-Smith, J., and Edwards, A. C. (2006). Seasonality and fire severity in savanna landscapes of monsoonal Northern Australia. Int. J. Wildland Fire 15, 541-550. doi: 10.1071/wf05111

Ryan, K. C., and Reinhardt, E. D. (1988). Predicting post-fire mortality of seven western conifers. Can. J. For. Res. 18, 1291-1297. doi: 10.1139/x88- 199

Simard, A. J. (1991). Fire severity, changing scales, and how things hang together. Int. J. Wildland Fire 1, 23-34. doi: 10.1071/wf9910023

Simon, H. A. (1974). "The organization of complex systems," in Hierarchy Theory: The Challenge of Complex Systems, ed. H. H. Pattee (New York, NY: Braziller).

Simpson, N. (2006). Modeling of residential structure fire response: exploring the hyper-project. J. Oper. Manage. 24, 530-541. doi: 10.1016/j.jom.2005.11.010

Sitters, H., Di Stefano, J., Christie, F. J., Sunnucks, P., and York, A. (2015). Bird diversity increases after patchy prescribed fire: implications from a beforeafter control-impact study. Int. J. Wildland Fire 24, 690-701. doi: 10.1071/WF 14123

Skinner, W. R., Flannigan, M. D., Stocks, B. J., Martell, D. L., Wotton, B. M., Todd, J. B., et al. (2002). A $500 \mathrm{hPa}$ synoptic wildland fire climatology for 
large Canadian forest fires, 1959-1996. Theor. Appl. Climatol. 71, 157-169. doi: 10.1007/s007040200002

Skinner, W. R., Stocks, B. J., Martell, D. L., Bonsal, B., and Shabbar, A. (2000). "The relationship between area burned by wildland fire in Canada and circulation anomalies in the mid-troposphere," in Biomass Burning and Its InterRelationships with the Climate System, eds J. L. Innes, M. Beniston, and M. M. Verstraete (Dordrecht: Springer), 101-125. doi: 10.1007/0-306-47959-1_7

Stocks, B. J. (1987). Fire behavior in immature jack pine. Can. J. For. Res. 17, 80-86. doi: 10.1139/x87-014

Stocks, B. J. (1989). Fire behavior in mature jack pine. Can. J. For. Res. 19, 783-790. doi: 10.1139/x89-119

Stocks, B. J., and Walker, J. D. (1972). Fire Behavior and Fuel Consumption in Jack Pine Slash in Ontario. Marie, ON: Great Lakes Forestry Centre Arboretum.

Stull, R. (2017). Practical Meteorology: An Algebra-Based Survey of Atmospheric Science. University of Vancouver, BC. Available online at: https://www.eoas.ubc. ca/books/Practical_Meteorology/ (accessed September 15, 2020).

Sullivan, A. L. (2017). Inside the inferno: fundamental processes of wildland fire behaviour. Part 2. Heat transfer and interactions. Curr. For. Rep. 3, 150-171. doi: $10.1007 / \mathrm{s} 40725-017-0058-\mathrm{z}$

Taylor, S. W., and Alexander, M. E. (2006). Science, technology, and human factors in fire danger rating: the Canadian experience. Int. J. Wildland Fire 15, 121-135.

Taylor, S. W., and Alexander, M. E. (2017). Field guide to the Canadian Forest Fire Behavior Prediction System, 3rd EDn. Special Report, NO. 11. Edmonton, Alberta: Canadian Forest Service, Northern Forestry Centre.

Taylor, S. W., McApline, R. S., and Magnussen, S. (2011). "Projecting national resource demand to support resource sharing," in Proceedings of the 5th International Wildland Fire Conference, Sun City.

Taylor, S. W., Woolford, D. G., Dean, C. B., and Martell, D. L. (2013). Wildfire prediction to inform management: statistical science challenges. Stat. Sci. 28, 586-615. doi: 10.1214/13-sts451

Taylor, S. W., Wotton, B. M., Alexander, M. E., and Dalrymple, G. N. (2004). Variation in wind and crown fire behaviour in a northern jack pine black spruce forest. Can. J. For. Res. 34, 1561-1576. doi: 10.1139/ x04-116

Turner, M. G., Dale, V. H., and Gardner, R. H. (1989). Predicting across scales: theory development and testing. Landsc. Ecol. 3, 245-252. doi: 10.1007/ bf00131542

Turner, R., Roberts, N., and Jones, M. D. (2008). Climatic pacing of Mediterranean fire histories from lake sedimentary microcharcoal. Glob. Planet. Change 63, 317-324. doi: 10.1016/j.gloplacha.2008. 07.002

Van der Hoven, I. (1957). Power spectrum of horizontal wind speed in the frequency range from 0.0007 to 900 cycles per hour. J. Meteorol. 14, 160-164. doi: 10.1175/1520-0469(1957)014<0160:psohws>2.0.co;2
Van Wagner, C. E. (1977a). A Method of Computing Fine Fuel Moisture Content throughout the Diurnal Cycle. Inf. Rep. PS-X-69. Chalk River, ON: Canadian Forestry Service.

Van Wagner, C. E. (1977b). Conditions for the start and spread of crown fire. Can. J. For. Res. 7, 23-34. doi: 10.1139/x77-004

Van Wagner, C. E. (1987). Development and structure of the Canadian Forest Fire Weather Index System. For. Tech. Rep. 35. Ottawa: Canadian Forestry Service.

Wang, X. K., Studens, K., Parisien, M. A., Taylor, S. W., Candau, J. N., Boulanger, Y., et al. (2020). Projected changes in fire size from daily spread potential in Canada over the 21st century. Environ. Res. Lett. doi: 10.1088/1748-9326/aba101. [Epub ahead of print].

White, C. A., Olmsted, C. E., and Kay, C. E. (1998). Elk, aspen and fire in the Rocky Mountain national parks of North America. Wildlife Soc. Bull. 26, 449-462.

Wiitala, M. R., and Carlton, D. W. (1994). "Assessing long-term fire movement risk in wilderness fire management," in Proceedings of the 12th International Conference on Fire and Forest Meteorology, Jekyll Island.

Wiken, E. B. (1986). 'Terrestrial Ecozones of Canada'. Ottawa: Environment Canada.

Wotton, B. M. (2009). Interpreting and using outputs from the Canadian Forest Fire Danger Rating System in research applications. Environ. Ecol. Stat. 16, 107-131. doi: 10.1007/s10651-007-0084-2

Wotton, B. M., Flannigan, M. D., and Marshall, G. A. (2017). Potential climate change impacts on fire intensity and key wildfire suppression thresholds in Canada. Environ. Res. Lett. 12:095003. doi: 10.1088/1748-9326/aa7e6e

Yang, J., Tian, H., Tao, B., Ren, W., Kush, J., Liu, Y., et al. (2014). Spatial and temporal patterns of global burned area in response to anthropogenic and environmental factors: reconstructing global fire history for the 20th and early 21st centuries. J. Geophys. Res. 119, 249-263. doi: 10.1002/2013jg 002532

Yiou, R., Fuhrer, K., Meeker, L. D., Jouzel, J., Johnsen, S., and Mayewski, P. A. (1997). Paleoclimatic variability inferred from the spectral analysis of Greenland and Antarctic ice core data. J. Geophys. Res. 102, 26441-26454. doi: 10.1029/ $97 \mathrm{jc} 00158$

Conflict of Interest: The author declares that the research was conducted in the absence of any commercial or financial relationships that could be construed as a potential conflict of interest.

Copyright (c) 2020 Taylor. This is an open-access article distributed under the terms of the Creative Commons Attribution License (CC BY). The use, distribution or reproduction in other forums is permitted, provided the original author(s) and the copyright owner(s) are credited and that the original publication in this journal is cited, in accordance with accepted academic practice. No use, distribution or reproduction is permitted which does not comply with these terms. 


\section{APPENDIX}

TABLE A1 | Examples of some types of fire management decisions in Canada and links to fire activity.

\begin{tabular}{|c|c|c|c|}
\hline Decision type & Description and fire behavior dependency & $\begin{array}{l}\text { Typical spatial } \\
\text { level }\end{array}$ & $\begin{array}{l}\text { Typical time } \\
\text { span }\end{array}$ \\
\hline Level of protection & $\begin{array}{l}\text { Determining activities and resource requirements and activities required to meet strategic } \\
\text { objectives, including area burned objectives. }\end{array}$ & Provincial & Multi-year \\
\hline Capital acquisition & $\begin{array}{l}\text { Procurement of fixed assets: aircraft, base facilities, equipment, depending on the long term } \\
\text { expectation of number and location of fires of different complexity. }\end{array}$ & Provincial & Multi-year \\
\hline Staffing & $\begin{array}{l}\text { Recruiting the appropriate number of permanent and seasonal staff with the appropriate } \\
\text { knowledge, skills and abilities carry out the job functions required to achieve the strategic and } \\
\text { operational objectives, depending on the long term expectation of the number of fires of } \\
\text { different complexity. }\end{array}$ & Provincial & $\begin{array}{l}\text { Multi- } \\
\text { year/Annual }\end{array}$ \\
\hline Base location & $\begin{array}{l}\text { Permanent facility at which aircraft and fire crews are stationed during the fire season for } \\
\text { deployment to operations, depending on the long term expectation of the number and location } \\
\text { of fires of different complexity. }\end{array}$ & Provincial & Multi-year \\
\hline Program budgeting & $\begin{array}{l}\text { Budgetary authority to fund capital, fixed preparedness and (variable) response resources to } \\
\text { achieve strategic objectives depending on the annual expectation of the number of incidents of } \\
\text { different complexity. }\end{array}$ & Provincial & Annual \\
\hline Home basing & $\begin{array}{l}\text { Allocation of airtankers and fire crews among potential home-bases such that their average } \\
\text { annual ferrying cost/time to meet daily deployment requirements is minimized (after MacLellan } \\
\text { and Martell, 1996) depending on the expected number and location of daily fire starts } \\
\text { exceeding ground resources. }\end{array}$ & Provincial & Annual \\
\hline Contracting & $\begin{array}{l}\text { Multi-year contracting for services such as aircraft; seasonal contracting for resources such as } \\
\text { helicopters, mobile aviation fuel services; short term contracting for helicopters, Type } 3 \\
\text { firefighters, heavy equipment, logistical support (e.g., Donovan, 2006) depending on the } \\
\text { expected fire load. }\end{array}$ & $\begin{array}{l}\text { Provincial } \\
\text { Response } \\
\text { Center }\end{array}$ & $\begin{array}{l}\text { Multi-year, } \\
\text { annual } \\
<30 \text { days }\end{array}$ \\
\hline Resource sharing & $\begin{array}{l}\text { Exchanging (importing and exporting) resources to other provincial or national jurisdictions } \\
\text { through mutual aid agreements, depending on the expected fire load (number of new and } \\
\text { active fires of varying complexity) Resources are described by kind and type and may be used } \\
\text { in operational support or supervisory capacities at an incident (adapted from National Wildfire } \\
\text { Coordinating Group [NWCG], 2019). }\end{array}$ & $\begin{array}{l}\text { National } \\
\text { Provincial }\end{array}$ & $\begin{array}{l}+14 \text { days } \\
14 \text { days }\end{array}$ \\
\hline Day basing aircraft & $\begin{array}{l}\text { Deployment of airtankers to tanker bases overnight or early in the morning to satisfy anticipated } \\
\text { number of new fire starts exceeding ground resources based on the weather, ignitions, and fire } \\
\text { behavior forecast for the following day, and values at risk (after Islam, 1998). }\end{array}$ & Provincial & Daily \\
\hline Resource allocation & $\begin{array}{l}\text { Allocation of resources of different types (e.g., sustained action fire crews, helicopters) required } \\
\text { to contain fires depending on the expected number, size, complexity of new and active fires in } \\
\text { the planning period, and their stage of control, and priority. }\end{array}$ & $\begin{array}{l}\text { Provincial } \\
\text { Response } \\
\text { Center }\end{array}$ & $1-14$ days \\
\hline Detection routing & $\begin{array}{l}\text { Determining flight plans for discovering and locating wildfires from aircraft depending on } \\
\text { anticipated number and location of new ignitions, fire behavior and values at risk. }\end{array}$ & $\begin{array}{l}\text { Response } \\
\text { Center }\end{array}$ & Daily \\
\hline Dispatch & $\begin{array}{l}\text { The implementation of a command decision to move a resource or resources to an assigned } \\
\text { operational mission (National Wildfire Coordinating Group [NWCG], 2019) depending on the } \\
\text { expected near term fire growth and values at risk. }\end{array}$ & $\begin{array}{l}\text { Response } \\
\text { Center }\end{array}$ & Hourly \\
\hline Incident Action Plan & $\begin{array}{l}\text { An oral or written plan containing general objectives reflecting the overall strategy for managing } \\
\text { an incident. It may include the identification of operational resources and assignment and } \\
\text { provide direction for management of the incident during one or more operational periods } \\
\text { (National Wildfire Coordinating Group [NWCG], 2019). Includes an assessment of expected fire } \\
\text { behavior (spread, intensity) in the present and near term burning periods (1-3 days). }\end{array}$ & Incident & Daily \\
\hline $\begin{array}{l}\text { Resource } \\
\text { deployment and } \\
\text { utilization }\end{array}$ & $\begin{array}{l}\text { Decisions regarding the transport, placement, organization and tasking of different types of } \\
\text { resources (including tactics) to protect life and property or to contain fire perimeter growth using } \\
\text { direct or indirect attack methods depending on the stage of control, complexity of the fire, and } \\
\text { the expected fire behavior in the burning period. }\end{array}$ & Incident & Daily to Hourly \\
\hline
\end{tabular}


TABLE A1 | Continued

\begin{tabular}{|c|c|c|c|}
\hline Decision type & Description and fire behavior dependency & Typical level & $\begin{array}{l}\text { Typical time } \\
\text { span }\end{array}$ \\
\hline $\begin{array}{l}\text { Scouting/ } \\
\text { Reconnaissance }\end{array}$ & $\begin{array}{l}\text { Observing and assessing immediate and expected fire behavior in the burning period, } \\
\text { values-at-risk, suppression activity, and other critical factors to facilitate decisions on } \\
\text { strategy and tactics needed for fire suppression as per Table } 2 \text {. }\end{array}$ & Incident & Daily \\
\hline $\begin{array}{l}\text { Entrapment } \\
\text { avoidance }\end{array}$ & $\begin{array}{l}\text { A process used to improve the safety of personnel on the fireline, which emphasizes } \\
\text { tools and tactics available to prevent being trapped in a burn over situation. This } \\
\text { process includes appropriate decision making through risk management, application of } \\
\text { LCES, use of pre-established trigger points, and recognition of suitable escape routes } \\
\text { and safety zones (National Wildfire Coordinating Group [NWCG], 2019). The safety plan } \\
\text { is informed by the expected fire behavior in burning period. }\end{array}$ & Incident & Immediate \\
\hline Tactical withdrawal & $\begin{array}{l}\text { Withdrawal of personnel threatened by an active fire front to a safety zone depending } \\
\text { on the immediate fire intensity and spread. }\end{array}$ & Incident & Immediate \\
\hline
\end{tabular}

